\title{
How Does Firm Life Gycle Affect Board Structure? Evidence from China's Listed Privately Owned Enterprises
}

\author{
Yunhe $\mathrm{Li}^{1}$ and Xiaotian Tina Zhang ${ }^{2}$ \\ ${ }^{1}$ East China Normal University, China, and ${ }^{2}$ Saint Mary's College of California, USA
}

ABSTRACT Using data from China's listed privately owned enterprises (POEs) during the period from 2002 to 2014, we explore the effects of firm life cycle on board structure. We find that the board size of China's listed POEs declines over firm life cycle, and there is a trend of separation for board chair-CEO duality while board independence remains almost static. We further provide evidence that board size and independence are determined by the benefits of monitoring and advisory roles of the boards through all the stages of firms' life cycle with different drivers. The impact of CEO power on board chair-CEO duality is determined by the benefits and costs of separation of board chair, and CEOs are supported at all stages of firms' life cycle. This article sheds light on the dynamic board structure in an emerging economy where the external corporate governance is weaker than that of developed countries. Our findings suggest that the board structures of China's listed POEs are adjusted at various stages of firms' life cycle, and the adjustments are mostly based on the resources brought by the new board of directors.

KEYwORDs board chair-CEO duality, board independence, board size, board structure, China, firm life cycle, privately owned enterprises (POEs)

\section{INTRODUGTION}

Boards of directors are widely recognized as playing a central role in corporate governance (Hermalin \& Weisbach, 1998). But the determinants of an optimal board structure, which are critical for improving board effectiveness, remain inconclusive. Existing work focuses mainly on such questions from a static perspective (e.g., Boone \& Field, 2007; Gillan, Hartzell, \& Starks, 2006; Hussain \& Mallin, 2003; Wintoki, Linck, \& Netter, 2012). Adams, Mansi, and Nishikawa (2010) demonstrate that the effectiveness of board function depends on board composition. Coles, Daniel, and Naveen (2008) suggest that there is no one optimal board size for all firms, because individual firms are associated with different features. Linck, Netter, and Yang (2008) point out that board structure 
is determined by firm characteristics as well as CEO characteristics and power. Organization structure theory (Cummings, 2004) proposes that board structure should change in response to the development of a firm's internal and external environments. A very few studies are emerging to examine the evolution of board structure. For instance, by tracking US firms' board development for 10 years after their IPOs, Boone and Field (2007) find that both board size and independence increase as the US firms grow and diversify their investments over time. Lehn, Patro, and Zhao (2009) report a similar result with the data of US companies for a longer time horizon. However, these prior studies, which track board structure over a long-term time frame, have not dynamically captured the prominent features of board structure at different firm stages across firm life cycle.

Greiner (1972) points out that firm life cycle is essential for corporate behavior and structure. Based on firm life cycle theory, a firm is associated with specific characteristics at various life cycle stages (Adizes, 1989; Drazin \& Kazanjian, 1990; Miller \& Friesen, 1984), such as ownership structure, organizational behavior, and corporate strategies. As a result, the firm will experience different agency problems and resource-seeking needs, and it will be motivated to change its board of directors. So, the board structure at its life cycle stages will change. Lynall, Golden, and Hillman (2003) established a theoretical framework to explain how board composition changes from adolescence to maturity by a multi-theoretic view (agency, resource dependence, etc.), which provides insight into the influence of life cycle on board structure. Filatotchev and Wright (2005) conceptually analyze the life cycle dynamics of corporate governance. Surveys of US firms by Roche (2009) document the narrative of the board roles during different life cycle states of an organization. The literature cited above has established a theoretical connection between corporate board and firm life cycle; yet empirical investigation on this topic is still under-explored. Our article aims to fill this gap with a comprehensive empirical investigation on the question how firm life cycle affects board structure.

Complementary to most studies on boards using data from developed countries, the article aims to examine how firm life cycle affects board structure for the POEs in Chinese settings, which are characterized by a weak external governance environment. Compared with developed countries, China's privatelyowned enterprises (POEs) are growing in a weak external governance system, including incomplete external market mechanisms and an incomplete law system (Luo, Wan, Cai, \& Liu, 2013; Peng, 2004; Young, Peng, Ahlstrom, Bruton, \& Jiang, 2008). To mitigate the risk associated with weak external corporate governance, it is particularly vital for capital market investors to foster an efficient internal corporate governance mechanism for Chinese POEs. Meanwhile, the POEs in China's private sector are still disadvantaged in accessing external resources compared to China's state-run companies (Hu, Tam, \& Tan, 2010; Peng, Sun, Pinkham, \& Chen, 2009), even though they currently account for more than half of the entire Chinese economy (Huang, 2010). As a result, China's POEs would probably be more motivated to improve their board structure across their 
various developmental stages in order to achieve a sustainable firm growth. Additionally, POEs in China are mostly run by the founders or large shareholders with concentrated ownership (Luo et al., 2013; Peng et al., 2009). Thus, the Chinese POEs may experience less serious agency problems between shareholders and managers than SOEs, leading to a lower demand for the POEs to appoint many directors to execute the board's monitoring function. Therefore, the Chinese POEs, given these elements and their weaker external governance environment, provide us a special opportunity to empirically investigate the dynamics of board structure across firm life cycle.

The article aims to address how firm life cycle affects board structure, with a focus on the dynamics of board functions of China's POEs in response to the changes of their external and internal environment. To answer such questions, we first investigate whether firm life cycle affects board structure based on agency theory and resource dependence theory, which would offer a dynamic view for understanding board structure dynamics in conjunction with firm life cycle. We then further investigate how firm life cycle affects board structure, which would help us to understand the drivers in forming firms' board structure at different stages of firm life cycle. Given the lack of widely accepted classification methods of firm life cycle, we propose a new method to classify firm life cycle stages by scoring on four indicators: sales growth rate, capital expenditure, earnings retained ratio, and firm age by industry. The new classification method offers a novel tool to examine the dynamic relation between board structure and firm life cycle.

Using data from China's listed POEs, we find that the board size of China's listed POEs declines during firm life cycle, and board chair-CEO duality shows a trend toward separation while board independence remains static. The effects of CEO characteristics on board structure are significant both at the growth and decline stages of a firm. These findings are robust in response to our best attempts to address endogenous concerns and various proxies for firm life cycle.

Our article touches upon several strands of existing literature on board structure. First, prior literature on board structure dynamics primarily studies its evolution in developed countries. In this article we empirically investigate board dynamics through firm life cycles in China. The study of China's listed POEs offers more meaningful insights into understanding the board of directors, which is a marketoriented internal corporate governance mechanism in the weak external corporate governance of China. Our work empirically enriches prior analytical studies on board dynamics through firm life cycle. Moreover, it also provides a supplement to existing board-evolution studies, which have been mainly based on evidence from developed countries.

Second, we also contribute to the literature on the determinants of board structure. Our study provides corroborating evidence regarding the effects of firm life cycle on board structure of China's listed POEs. To our best knowledge, this article is the first to provide a comprehensive investigation into board structure in firm life cycle. 
Third, we offer a novel method to measure firm life cycle. A life cycle score is constructed based on sales growth rate, retained earnings, capital expenditure, and firm age. Our new measure for firm life cycle contributes to the existing literature that employs dividends as a proxy (Anthony \& Ramesh, 1992; DeAngelo, DeAngelo, \& Stulz, 2006), and captures the uniqueness of an emerging stock market whose firms are relatively younger and pay a fewer dividends compared to US companies.

Last but not least, our findings are beneficial for business practitioners seeking to form an efficient board at various stages of firms' life cycles. Given the significant dynamics of board structure over the life cycle of China's listed POEs, the decision-makers of POEs should proactively adjust board structure to improve firm competition. Second, the supervisory authorities for listed companies in China should not require all companies to comply with one corporate governance structure. It is preferable for the policy maker to establish some guidance and allow firms to adjust their board structure independently.

The rest of the article is organized as follows. Section 2 discusses the institutional background of China's economic reform; section 3 develops hypotheses; section 4 covers variables construction, sample selection and empirical methods; section 5 reports the results; and section 6 concludes.

\section{POEs' Development and Characteristics of Corporate Boards in China}

Since China's economic reform in the 1980s, the private economy in China has been growing rapidly. Following the corporatization reform of SOEs since the 1990s, parts of state-owned enterprises (SOEs) have been restructured as privately controlled firms. The protection of private property rights was approved by the National People's Congress in 2004, and more POEs that are managed and controlled by founders are emerging. Recently, the POEs are becoming an important contributor to the whole economy in China, but they still suffer a disadvantage compared to state-owned companies in obtaining governmental resources (Poncet, Steingress, \& Vandenbussche, 2010). Meanwhile, the POEs also experience less intervention from the Chinese government; therefore, they have more rights to make their own decisions in response to the changes of their internal or external environment changes.

As the starting point of China's corporate governance reforms, the Chinese Company Law implemented in 1994 articulates the responsibilities, rights, and liabilities of the board of directors for listed companies. In 2001, the China Securities Regulatory Commission issued 'the guidance of establishment of independent directors for listed companies', which requires that the listed companies in China employ independent directors in their boards of directors: for example, a board of directors should at least have two members, and the proportion of independent directors of listed companies shall not be less than one-third. In 2002, the China Securities Regulatory Commission and the State Economic 
and Trade Commission jointly issued the corporate governance codes, which also require that listed companies in China establish an independent director system. In this way, the system of board of directors mainly adopted from the Western economics was established among China's listed companies.

China's listed POEs provide a special sample for empirically testing the dynamics of board structure across firm life cycle for several reasons. First, China is an emerging capital market whose corporate governance is still poorly developed (Luo et al., 2013). The investigation of corporate boards in China can complement the understanding of the board structure and functions in a sophisticated corporate governance system seen in developed economies. Second, unlike SOEs that are affiliated with the Chinese government, China's POEs are subject to market-based competition and corporate governance. The operation of boards of directors differs markedly between state-owned enterprises and POEs. State-owned enterprises (SOEs) are legally governed by the State-Owned Assets Supervision and Administration Commission (SASAC), a representative of the State Council. The SASAC is responsible for overseeing, regulating, and managing SOEs, such as appointing directors and CEOs. Consequently, the adjustment of board structure for SOEs is less market-oriented. POEs are starved as a result of less government support, but they enjoy limited government intervention. POEs can self-adjust their board structure in response to contingent organizational environments. As a result, China's listed POEs offer a special sample to examine boards of directors; that is, a market-oriented internal corporate governance mechanism in a weak external corporate governance system of China.

\section{THEORETICAL BACKGROUND AND HYPOTHESES}

\section{Roles and Structure of a Corporate Board}

Berle and Means (1932) propose a modern corporate structure by a separation between ownership (shareholder) and control (management). Jensen and Meckling (1976) document the principal-agency relationship in modern corporate structure between the firm investors and managerial teams. With ownership becoming widely dispersed, monitoring managers is difficult. The board of directors is responsible, on behalf of shareholders, for monitoring the managerial team and mitigating agency conflicts (Johnson, Daily, \& Ellstrand, 1996). Agency theory also acknowledges that the effectiveness of a board is related to board structure (Fama \& Jensen, 1983). As ownership disperses, board size may be increased so the board can maximize representatives for the shareholders. Additionally, independent directors are widely thought to be more effective at monitoring managers, because their interests are independent from the management team (Borokhovich, Parrino, \& Trapani, 1996; Brickley, Coles, \& Terry, 1994). Consequently, the monitoring power of a board may be improved by raising the ratio of independent directors. 
In addition to the monitoring role, boards have an advisory role (this includes strategic advising, resources offering, and external connection). Resource dependence theory (Hillman, Cannella, \& Paetzold, 2000; Pfeffer \& Salancik, 1978) argues that organizations will try to exert control over their contingent environment by co-opting the resources needed for development. Accordingly, resource dependence theory views boards as resource providers for firms (Carpenter \& Westphal, 2001; Lynall et al., 2003). Dallas (1996) argues that the board of directors can help a company obtain information from external environments, exchange it within the organization, and offer special advice and resources to the company. Hillman and Dalziel (2003) propose that directors can help to secure valuable resources and provide access to key constituents for firms. Besides, directors can introduce business relationships for companies (Brickley et al., 1994), such as accessing external financial resources (Hillman \& Dalziel, 2003) and establishing connections in social networks (Khurana, 2001). The advisory role of a board places much emphasis on the resources gathered from different directors to raise an organization's power, which not only may result in a higher ratio of independent directors in the board, but also may contribute to a larger board.

\section{Firm Life Gycle and Board Structure Dynamics}

Since Chandler's (1962) seminal work on organization life cycle, many studies have focused on the classification and characteristics of life-cycle stages and have linked the life-cycle stage to organization performance (Adizes, 1989; Greiner, 1972; Miller \& Friesen, 1984). Central to the life cycle theory is that a firm's internal and external environment varies across different stages of the life cycle (Anderson \& Zeithaml, 1984; Dodge \& Robbins, 1992). Among the differences across life cycle stages are complexity of systems and structures, managerial capabilities, and changing resource needs (Jawahar \& McLaughlin, 2001). The start-up stage of a firm is the period in which firm size is usually small, and the founders of the firm are also its owners, and operate the firm by themselves. It is necessary for the firm's survival to obtain resources to enter the marketplace (Jawahar \& McLaughlin, 2001). The firm in a growth stage is likely to actively seek to expand (Jawahar \& McLaughlin, 2001). As the firm expands rapidly, the founders may be inclined to have external professional managers to operate the firm, and the separation between managerial control and ownership is emerging. At the maturity stage, the growth rate has slowed down; the firm is established within a number of business segments, and it is operated by a professional management team. Meanwhile, the firm usually has the capacity for creating cash flows and obtaining additional capital (Dodge, Fullerton, \& Robbins, 1994), so it may need fewer external resources than at other stages. The firm at the decline stage is characterized by a reducing growth rate, growth of bureaucracy within the organization, and increasing internal prevarication, all of which would present it with a threat to survival (Jawahar \& McLaughlin, 2001). 
Therefore, it is necessary for the firm to access external resources (advice) to develop new products or strategically restructure.

Boards of directors play an important role in monitoring and advising for companies. The monitoring function is to prevent managers' value-destroying behavior, while the advising function aims to support the development of the firm by offering resources to the firm. The optimal board structure is a function of the cost and benefit acquired from board monitoring and advising (Adams \& Ferreira, 2007; Raheja, 2005). The POEs in China still experience an inferior status compared to state-owned companies in competition for governmental resources (Poncet et al., 2010). Therefore, the POEs need to actively seek more resources to support their development. Many POEs in China are opting to appoint directors who have strong and effective political connections (Fan, Wong, \& Zhang, 2007; Li, Meng, Wang, \& Zhou, 2008). On the other hand, the POEs in China are usually operated by their founders and larger shareholders with concentrated ownership (Luo et al., 2013; Peng et al., 2009). Therefore, the agency problems between shareholders and managers may be less serious, which may lead to a lower demand for the firms to appoint more directors to execute the board's monitoring function than to perform its advising function. Given the board functions and life-cycle characteristics above, board structure could be dynamic in response to support firm growth across firm life cycle. We then propose a series of hypotheses on the board structure and firm life cycle for China's POEs, including the different effects of life-cycle stages on board structure and the drivers of such different effects.

\section{Board Structure Dynamics across Firm Life Gycle}

Board size. Prior literature has demonstrated that board structure needs to be adjusted during a firm's life cycle to assure the firm's survival and development (Filatotchev \& Wright, 2005). As it matures, a firm becomes more complex. It needs the essential resources to support its expansion, maintenance, and restructuring. As a result, the board's advisory role is shifting. When going public, the firm's ownership structure is much dispersed, leading to severe agency problems; so, the board's monitoring role must be adjusted accordingly.

Resource dependency theory suggests that firms would exert control over their environment by acquiring critical resources for development (Pfeffer \& Salancik, 1978). Boards of directors are expected to provide advice and introduce resources for companies (Golden \& Zajac, 2001; Hillman \& Dalziel, 2003). Pfeffer (1972) finds that board size is related to a firm's environmental needs. Because the firm's internal ability to create resources (e.g., cash flow) develops across the firm's life cycle, board size may be expected to decline through its life cycle. Coles et al. (2008) and Lehn et al. (2009) suggest that firms appoint more board members to monitor their expansion stage, so that board members can represent various shareholders. Boone and Field (2007) argue that new board members are needed for better monitoring at the growing and expanding stages of a firm than at the 
maturity stage; and Goodstein, Gautam, and Boeker (1994) provide evidence that large boards can fulfill the resource-provision role, since board members possess more resources for firms.

Resource dependence theory predicts that board size decreases in a firm's life cycle, while agency theory predicts that board size increases in a firm's life cycle. The dynamic organization characteristics predicted by the two theories above can be generally applied for any companies, including China's POEs. Moreover, China's POEs have their special characteristics, as most of them are managed and controlled by their founders with concentrated ownership (Peng et al., 2009), and they experience an inferior status than state-owned companies in obtaining governmental resources in China across firms' life cycle (Poncet et al., 2010). As a result, resource constraint could be the first problem for the growth of China's POEs. Especially at the growth stage, they would be inclined to invite more directors to support that growth. Later, at the maturity and decline stages, the firms' ability to create resources by themselves would be improved. Their need for additional directors gradually diminishes. Though the firms at such stages may experience an agency problem caused by the separation of ownership and control, the conflicts between shareholders and managers may be not hugely serious, because China's POEs are usually operated by their founders or larger shareholders. Therefore, we propose the following hypothesis:

Hypothesis 1a: Board size of China's POEs will be larger at the growth stage than at the maturity stage and the decline stage.

Board independence. Independent boards are documented to be effective at monitoring due to the limited influence from firm's top management (Borokhovich et al., 1996). On one hand, agency theory implies that board independence increases during the firm life cycle. Boone and Field (2007) argue that independent boards provide effective monitoring, implying that an increase of board independence across firm life cycle enhances the monitoring role of boards. On the other hand, resource dependency theory predicts that board independence decreases in firm life cycle. Board independence is related to outside directors. ${ }^{[1]}$ Outside directors are expected to bring valuable resources for firms (Pfeffer \& Salancik, 1978). Peng (2004) finds that resourceful outside directors are likely to have a positive influence on firm performance. When a company's internal resources (e.g., cash flow) remain adequate across the firm's life cycle, the resources needed from the external environment may decrease (Jawahar \& McLaughlin, 2001); this may result in a decreasing ratio of independent directors in the board across firm life cycle. Other studies suggest that a company with multiple segments will get substantial benefits from the outside directors (Coles et al., 2008; Fama \& Jensen, 1983; Lehn et al., 2009). Adams and Ferreira (2007) and Raheja (2005) point out that firms tend to have more outside independent directors to monitor the CEO with more power. 
China's POEs are characterized by controlling founders and a status inferior to state-owned companies in obtaining governmental resources (Poncet et al., 2010). Consequently, the agency problem between the $\mathrm{CEO}$ and shareholders may not be so serious, even at the maturity and decline stages. Therefore, in order to release the resources constraint, a firm is likely to employ more independent directors than to defend against an agency problem. China's POEs would add more outside directors for accessing external resources at the growth stage, while the percentage of independent directors would decrease due to defending against agency problem at the maturity and decline stages. Therefore, the following hypothesis is proposed:

Hypothesis 1b: There will be more board independence at the growth stage than at the maturity stage and the decline stage.

Board chair-CEO duality. After going public, firm ownership has been dispersed and the CEO duality is gradually separated (Elsayed, 2010; Peng, Li, Xie, \& Su, 2010). Elsayed (2010) points out that the centralized power of a CEO (such as CEOboard chair duality) would be delivered to managers in order to invite them for professional operating. China's POEs are mostly characterized with high ownership concentration (Luo et al., 2013; Peng et al., 2009). The control by a Chinese POE's founders and/or large shareholders could be gradually separated (Peng et al., 2010) to enhance professional operation as the company grows. As a result, the probability of splitting the roles of the CEO and chair increases when the POEs mature (Filatotchev \& Wright, 2005; Lasfer, 2006). Thus, the duality could be more concentrated at the growth stage than that at the maturity and decline stages.

Meanwhile, compared to state-owned companies, China's POEs still suffer an inferior status in obtaining governmental resources (Poncet et al., 2010). As a firm grows, its dependence on external environments is enhanced, and it must seek more resources by exchanging power with different providers (Hillman et al., 2000; Pfeffer \& Salancik, 1978). The need to obtain resources leads to the power concentration in the organization being dispersed, so that the board chair-CEO duality will become separated through a firm's life cycle. That is, the duality could be less dispersed at the growth stage than at the maturity and decline stage. Both resource dependence theory and agency theory predict a trend of split for board chair-CEO duality. Therefore, the following hypothesis is proposed:

Hypothesis 1c: Board chair and CEO are more likely to be concentrated at the growth stage than at the maturity stage and the decline stage.

\section{Determinants of Board Structure across Firm Life Cycle}

The set of hypotheses above suggests the different effects of life cycle on board structure. We now further investigate the drivers of such different effects across firm life cycle.

Board structure (mainly for board size and board independence) is determined by the benefits and costs associated with board functions (Adams \& Ferreira, 2007; 
Raheja, 2005). A firm benefits from the board with its monitoring and advisory roles. Adding more directors, especially independent directors, can be essentially beneficial for the firm's growth, since more directors expand its connection. This may not only be convenient to accessing external resources, but also may help monitor its agency problems (Coles et al., 2008). However, when the firm can create sufficient resources (e.g., cash flows) by itself, or when it experiences benign agency problems, the firm is reluctant to continue increasing board size and independence. Therefore, the benefits of monitoring and advising related to adjusting board structure may change with the firm's needs. In terms of the costs of monitoring and advising associated with adjusting the board, the expansion of the current board increases the costs caused by free riding and coordination among board members (Adams \& Ferreira, 2007; Raheja, 2005). High costs are usually embedded for transferring information to the external independent directors and coordinating more directors to reach a decision. As a result, employing more independent directors to conduct the monitoring role may not be the optimal choice for firms with high information asymmetry (Maug, 1997). Adams and Ferreira (2007) state that board size and independence would decline with the increase in costs associated with the board's monitoring and advising functions.

In addition to board size and independence, board chair-CEO duality is an important component of board structure. The duality is the outcome from balancing the benefits and the costs from their splitting (Elsayed, 2010). The separation of board chair and CEO in a firm is related to releasing the existing resource constraints and to triggering more agency problems. To support firm growth, it is necessary for the firm's existing controllers to exchange their control power with external resources, leading to the separation of board chair and CEO (Pfeffer \& Salancik, 1978). It is also important for the firm to further divide its ownership and management; thus, conflicts between shareholders and controllers (managers) emerge, usually accompanied by the separation of board chair and CEO. The firm can obtain benefits from the separation of board chair and CEO, such as accessing external resources and hiring external talents for firm management. Costs of separation of board chair and CEO mainly consist of information costs and CEO entrenchment costs. The information costs emerge when specific information is transferred between the CEO and the chair. The CEO entrenchment costs are mainly defined as the influential cost when a powerful CEO still intends to intervene in the regular board decisions despite the separation of board chair-CEO duality. Board chair-CEO duality could be prominent when the information costs and CEO entrenchment costs are high.

\section{At the Growth Stage}

A firm actively expands its business at the growth stage (Jawahar \& McLaughlin, 2001). It needs to access more resources from both internal and external directors to maintain its control over contingent environments (Pfeffer \& Salancik, 1978). 
Meanwhile, during its expansion, the firm's ownership will gradually become separated, and then the agency problem between owners and managers emerges. More directors and independent directors can not only bring more resources for its growth, but also effectively monitor its managers. As we have seen, China's POEs are mostly managed or controlled by their founders (Peng et al., 2010), and they still operate at a disadvantage compared to stated-owned enterprises in terms of getting external resources (Poncet et al., 2010), in particular when the POEs are young (Chen, 2007). The above characteristics imply that China's POEs are starved for access to external resources, yet they experience a trivial agency problem. Therefore, adding new directors and independent directors could be mostly beneficial in leading China's POEs to release their existing resource constraints. Hence, board size and board independence will go up with the increase of the benefits of releasing resource constraints. On the other hand, the costs caused by adding such new board members will become higher, as the coordinating costs among more directors and the information transferring costs to external independent directors who may not know the firms' business in detail would increase. As a result, board size and board independence will decrease with respect to the increase of the costs caused by releasing resource constraints at the growth state. Therefore, we propose the following hypotheses:

Hypothesis 2-a1: At the growth stage when firms mainly experience resource constraints, board size/board independence will be positively associated with the benefits from adding directors.

Hypothesis 2-a2: At the growth stage when firms mainly experience resource constraints, board size/board independence will be negatively associated with the costs from adding directors.

At a firm's growth stage, splitting the roles of the $\mathrm{CEO}$ and chair becomes increasingly probable (Lasfer, 2006). The separation of board chair-CEO duality can help the firm to exchange its internal power with external resources and to hire professional managers. But at the growth stage, the agency problem between CEO and shareholders is weak, as the firm is most likely owned and controlled by its founders and larger shareholders; such a concentrated leadership structure implies that the firm is associated with high information costs and CEO entrenchment costs. At the growth stage, China's POEs suffer from serious resource constraints (Poncet et al., 2010) and are characterized by a concentrated power structure resulting from their concentrated ownership (Peng et al., 2010). China's POEs are eager to gather resources to support their growth. The separation of CEO and board chair is mostly driven by the benefits to exchange firm control with external resources. Therefore, for firms that release their resource constraints, the more benefits from the separation of board chair and CEO, the more dispersed the board chair-CEO duality would be. At the same time, even though firms' ownership is relatively dispersed, the POEs' agency costs are still low because the firms are relatively controlled by their founders. Consequently, the information transfer costs and CEO entrenchment costs from the separation of CEO and board chair are 
high. Hence, the more costs caused by the separation of board chair and CEO, the less dispersed board chair-CEO duality would be, due to releasing resource constraints. Therefore, we propose the following hypotheses:

Hypothesis 2-a3: At the growth stage when firms mainly experience resource constraints, board chair-CEO duality will be negatively associated with the benefits of the separation of board chair and CEO.

Hypothesis 2-a4: At the growth stage when firms mainly experience resource constraints, board chair-CEO duality will be positively associated with the costs of the separation of board chair and $C E O$.

\section{At the Maturity Stage}

At the maturity stage, a firm is characterized by large size, low growth rate, stable and fruitful cash flow, and a more dispersed ownership structure Jawahar \& McLaughlin, 2001). The firm will experience more serious agency problems and rely less on external resources than it did at the growth stage. Thus, the firm will reduce its need to access resources while management's desire to mitigate the agency problems between its shareholders and the professional CEO increases. It will embrace more directors to represent different shareholders and to execute the board's monitoring function. At the maturity stage, China's POEs have improved their competence in obtaining resources and gained their reputation in the society. Their disadvantage in accessing resources is diminishing (Zhang \& Keh, 2010). Meanwhile, the agency problem could become more serious for the Chinese POEs at the maturity stage due to more dispersed ownership. Therefore, it could be beneficial for the POEs to expand their board size and invite more independent directors to monitor their management team. Thus, board size and board independence will increase with such benefits going up, because of defending agency problems. Accompanied by such benefits, the costs mainly affiliated with strengthening the monitoring will be another important factor to be considered to defending against agency problems, such as the coordinating costs among more directors and the costs of transferring information to more independent directors. So, board size and board independence will decrease with the increase of such costs, because of the costs of defending agency problems. Therefore, we propose the following hypotheses:

Hypothesis 2-b1: At the maturity stage when firms mainly experience agency problems, board size/board independence will be positively associated with the benefits from adding director.

Hypothesis 2-b2: At the maturity stage when firms mainly experience agency problems, board size/board independence will be negatively associated with the costs from adding directors.

At the maturity stage of a firm, the board chair-CEO duality splits further, and then the agency problem between owners and managers becomes severe. At this point, 
the firm is able to generate adequate cash flows by itself. It will face many fewer resources constraints but a more severe agency problem than at the growth stage. Consequently, the firm could benefit less from the separation of board chair and CEO than by exchanging its internal power with external resources and hiring professional managers; meanwhile, the firm would suffer much higher agency costs. As for China's POEs, at the maturity stage, their ability to build cash flow resources is stronger, and ownership is more dispersed, and then the separation of board chair and CEO for the POEs would be more likely. Thus, China's POEs could mainly benefit from reducing the separation of CEO and board chair by dismissing the professional CEO to defend against agency problems, and could afford costs related to reducing separation, consisting of information transferring and CEO entrenchment costs. Thus, for firms defending agency problems, the more benefits come from the separation of board chair and $\mathrm{CEO}$, the more dispersed board chair-CEO duality would be; while the more costs come from the separation of board chair and GEO, the less dispersed board chair-CEO duality would be. Therefore, we propose the following hypotheses:

Hypothesis 2-b3: At the maturity stage when firms mainly experience agency problems, board chair-CEO duality will be negatively associated with the benefits of the separation of board chair and CEO.

Hypothesis 2-b4: At the maturity stage when firms mainly experience agency problems, board chair-CEO duality will be positively associated with the costs of the separation of board chair and $C E O$.

\section{At the Decline Stage}

At its decline stage, a firm experiences a negative growth rate and inertial organization, and the managers may be inclined to protect their own interests (Jawahar \& McLaughlin, 2001). Consequently, the firm at this stage needs to prevent the agency problem between the CEO and shareholders and to maintain its survival. It would be beneficial for the firm to monitor its managers and to seek advice on firm restructuring if it expands the board and adds more independent board members. China's POEs usually suffer an inferior status in terms of getting external resources compared with state-owned enterprises (Poncet et al., 2010). Therefore, it is important for the POEs to invite new directors to access external resources to help the firms maintain their restructuring. Meanwhile, China's POEs at the decline stage usually have a dispersed ownership structure. They still need to control the agency problem; however, the need won't be as strong as at the maturity stage because their CEOs have limited internal resources. Therefore, it is beneficial for the POEs at the decline stage to add more directors to conduct both the monitoring and the advising functions. Namely, for firms both defending against agency problems and releasing resource constraints, board size and independence would increase if the benefits go up. On the other hand, the coordination costs 
among more directors as well as information transfer costs to more independent directors to will increase. Consequently, board size and independence would decrease if the costs for defending against agency problems and releasing resource constraints increase. Therefore, we propose the following hypotheses:

Hypothesis 2-c1: At the decline stage when firms experience both resource constraints and agency problems, board size/board independence will be positively associated with the benefits from adding directors.

Hypothesis 2-c2: At the decline stage when firms experience both resource constraints and agency problems, board size/board independence will be negatively associated with the costs from adding directors.

At the decline stage, the board chair-CEO duality is further separated. A firm at this stage would suffer from restructuring and severe managers' agency problems. It's more important for the firm to mitigate the agency problem from the CEO and to maintain its survival from restructuring with an access to resources. At the decline stage, China's POEs with dispersed ownership have a weak ability to selfcreate resources. As a result, they would benefit from the separation of CEO and board chair to defend against agency problems and release resource constraints. We expect that the more benefits driven from the separation of board chair and CEO, the more dispersed board chair-CEO duality would be. At the same time, the firms also should accept the costs of information transferring and CEO related costs from such separation to defend against agency problem and release resource constraints. We argue that the more costs caused by the separation of board chair and $\mathrm{CEO}$, the less dispersed of board chair-CEO duality would be. Therefore, we propose the following hypotheses:

Hypothesis 2-c3: At the decline stage when firms experience both resource constraints and agency problems, board chair-CEO duality will be negatively associated with the benefits of the separation of board chair and CEO.

Hypothesis 2-c4: At the decline stage when firms experience both resource constraints and agency problems, board chair-CEO duality is positively associated with the costs of the separation of board chair and CEO.

\section{METHOD}

\section{Measures}

Board structure. Existing literature measures board structure by board size, board independence, and board chair-CEO duality (Boone \& Field, 2007; Coles et al., 2008; Lehn et al., 2009). In this article, board size (DSize) is defined as the total number of directors; board independence (IndpD) is defined as the ratio of independent directors to total number of directors on the board; board chair-CEO duality (Dual) is defined as whether the board chair and CEO are one person or 
not. We employ the dummy variable of board chair-CEO duality, which equals 1 when the $\mathrm{CEO}$ is also the board chair; otherwise it equals 0 .

Firm life cycle. Firm life cycle has been recognized and evidenced by numerous papers (Anthony \& Ramesh, 1992; DeAngelo et al., 2006; Miller \& Friesen, 1984). However, empirical studies engage inconsistent firm life-cycle measures. For instance, Anthony and Ramesh (1992) use composite scoring indicators of dividend payments, sales growth, capital expenditure, and firm age to classify firm life-cycle stages. Hribar and Yehuda (2007) also use the method proposed by Anthony and Ramesh to classify firm life-cycle stages in their research. DeAngelo et al. (2006) use the indicator of retained earnings to total equity ratio to measure firm life-cycle stages.

The article constructs an improved firm life-cycle indicator derived from the life-cycle indicator used by Anthony and Ramesh (1992). While maintaining the three indicators of sales growth, capital expenditure rates, and firm age, we do not employ dividend payments, because most of China's listed POEs offer few or no dividends. We introduce the indicator of retained earnings into our measure. Anthony and Ramesh (1992) insist that a company often has investment opportunities with positive NPV at the growth stage, its capital expenditure is high, and revenue is also growing fast. Retained earnings usually decline because of large investments at the growing stage, whereas they increase with firm development (Owen \& Yawson, 2010). As the company approaches the maturity stage, its growth slows; at the same time, retained earnings are increasing. At the decline stage, the company gradually sizes down. Retained earnings at the decline stage might be used for new investments to enable the business to revitalize, and at the same time, the management may intend to maintain more retained earnings.

Although using multi-indicator scoring to measure life cycle could be a more comprehensive way to describe firm characteristics at different stages, this approach neglects industry differences. We further improve our measurement by controlling for the industry differences at different life-cycle stages. Given the fact that the listed companies in China have passed beyond the start-up stage, the firm life cycle is classified into the three stages of growth stage, maturity stage, and decline stage.

Instead of using Anthony and Ramesh's (1992) dividend payments indicator, we introduce the variable of retained earnings into our measure. The composite scores have been conducted with consideration for industry differences. For every industry in each year, we sort the indicators of sales growth and capital expenditure in ascending order, and sort the indicators of retained earnings and firm age in descending order; then we classify each of the four indicators into three equal internals with a score ranging from 1 to 3 . We then summarize the individual score from the four indicators to obtain an aggregated composite score in each industry. After calibrating the composite score in each industry, we classify the full sample into three subsamples, as follows: the firms with the highest composite scores (from 
Table 1. Classification indicators of firm life cycle

\begin{tabular}{|c|c|c|c|c|c|c|c|c|}
\hline \multirow{2}{*}{$\begin{array}{l}\text { Variable } \\
\text { Stages }\end{array}$} & \multicolumn{2}{|c|}{ Sales growth } & \multicolumn{2}{|c|}{ Earnings retained } & \multicolumn{2}{|c|}{ Capital expenditure } & \multicolumn{2}{|c|}{ Firm age } \\
\hline & Features & Value & Features & Value & Features & value & Features & value \\
\hline Growth & High & 3 & Low & 3 & High & 3 & Low & 3 \\
\hline Maturity & Medium & 2 & Medium & 2 & Medium & 2 & Medium & 2 \\
\hline Decline & Low & 1 & High & 1 & Low & 1 & High & 1 \\
\hline
\end{tabular}

10 to 12) are defined as at the growth stage; the firms with the lowest scores (from 4 to 6) are defined as at the decline stage; and the ones with the scores from 7 to 9 are defined as at the maturity stage.

Table 1 shows that four indicators of firm life cycle (sales growth rate, retained earnings, capital expenditure, and firm age) have been employed to construct a composite score to classify different firm life-cycle stages. Several firm observations missing the four indicators have been deleted from our sample. Finally, our subsamples for the growth stage, maturity stage, and decline stage include 1956, 2232, and 1677 firm-year observations, respectively. ${ }^{[2]}$

Determinants of board structure. (a) Measurement for the benefits of monitoring and advising by board. Consistent with existing literature (Booth \& Deli, 1999; Bushman, Chen, Engel, \& Smith, 2004; Fama \& Jensen, 1983), we employ firm size, debt ratio, and segments to measure the benefit of monitoring and advising by board of directors. Firm age is also included in our testing. Managerial private benefit is measured by the firm's free cash flow (Jensen, 1986).

(b) Measurement for costs of monitoring and advising by board. Consistent with previous studies (Fama \& Jensen, 1983; Gaver \& Gaver, 1993; Smith \& Watts, 1992), we employ market-to-book ratio, standard variance of stock return to measure the costs of monitoring and advising by board of directors.

(c) Measurement of the determinants of board chair-CEO duality related to the benefits and costs from the separation of board chair and CEO. According to existing studies (Fama \& Jensen, 1983; Graham \& Harvey, 2001; Harris \& Raviv, 1998), the benefits of separation of board chair-CEO duality are usually high in large firms, so we use firm size to capture such benefits. And in accordance with the prior literature (Linck et al., 2008), the costs are mainly related to CEO capacities and the specific cost of information transferring, we use variables that include a firm's past performance, CEO tenure, CEO age, market-to-book ratio, and the standard deviation of stock return.

Control variables. Following Linck et al. (2007, 2008), this study uses managerial stock holdings to measure internal incentives and institutional stock holdings to control for the internal incentives and outside monitoring. The research also controls for industry and time effects. We measure the industry variable as a dummy variable: 
Table 2. Definition of main variables

\begin{tabular}{|c|c|}
\hline Variable & Definition \\
\hline Dsize & The number of board of directors \\
\hline Indpd & The proportion of independent directors on the board \\
\hline Dual & Equals 1 when the chair of board is also the $\mathrm{CEO}$, otherwise equals 0 \\
\hline Firm Life cycle & Defined in detail in the measurement section above \\
\hline logSize & The logarithm value of firm's total asset \\
\hline logSegmns & The logarithm value of business segments of the firm with adding one \\
\hline Debt & Represents the variable of firm's debt ratio \\
\hline FmAge & Computed since firm went public \\
\hline MTB & $\begin{array}{l}\text { The ratio of market-to-book value. This is obtained as market value of equity } \\
\text { plus book value of assets minus book value of equity, divided by book value of } \\
\text { assets. }\end{array}$ \\
\hline RetnStd & The standard deviation of the past twelve months' of the firm's stock returns \\
\hline MSstckH & The proportion of managerial shareholdings \\
\hline LgStckH & The proportion of institutional shareholdings among all shareholdings \\
\hline FCF & $\begin{array}{l}\text { Earnings before interest and after taxation }+ \text { depreciation and amortization - } \\
\text { the net operating capital - capital expenditure }) / \text { total assets }\end{array}$ \\
\hline Perf & Defined by the most recent two year's average capital return \\
\hline CeoAge & $\begin{array}{l}\text { Calculated by CEO's actual age when it } 60 \text { or less; indicator variable is used to } \\
\text { measure it when CEO's age is more than } 60\end{array}$ \\
\hline CeoTenure & The number of years CEO occupies theß position \\
\hline
\end{tabular}

the firm's industry equals 1 , otherwise 0 . Similarly, we proxy the time variables as year dummies: the annual year equals 1 , otherwise 0 .

The main variables discussed above are defined in detail in Table 2.

\section{Data and Sample}

Because in 2002 Chinese law required independent directors for listed companies, our study sample spans the period from 2002 to 2014. We retrieve the data from the CSMAR database. The initial data of our study include all of the listed POEs in China's Stock Market, and is classified into 13 industries according to the standard industrial classification of China Securities Regulatory Commission. The manufacturing industry is further divided into 10 sub-industries. Our data reflect 22 industries during the research period. Then we exclude financial companies, companies with key variables missing, and companies with corporate governance indicators missing, for a sample that includes 5,865 firm-year observations.

\section{Models}

We will first examine the board structure's differences over the firm life cycle. We use an independent sample t-test and non-parametric z-tests to examine board structure differences in firm life-cycle stages. Then we use the OLS method to regress equation (1) to investigate the impacts of firm life cycle on board structure (including board size (DSize), independent director (IndpD) and board chair-CEO 
Table 3. Descriptive statistics of board structure variables

\begin{tabular}{lcccccc}
\hline \hline Variable & Mean & Medium & Maximization & Minimum & Standard Deviation & Observation \\
\hline Dsize & 8.641 & 9 & 18 & 2 & 1.677 & 5865 \\
Indpd & 0.363 & 0.333 & 0.667 & 0 & 0.060 & 5865 \\
Dual & 0.264 & 0 & 1 & 0 & 0.441 & 5865 \\
\hline \hline
\end{tabular}

duality (Dual)).

$$
\text { DSize }_{i, t} \text { or Indp } D_{i, t} \text { or Dual }{ }_{i, t}=\gamma_{0}+\gamma_{1} \text { Lifecycl }_{i, t}+\gamma_{2} \text { Control }_{i, t}+\varepsilon_{i, t}
$$

where the variables of firm life cycle (Life cycle) includes the maturity stage and the decline stage as well as the corresponding composited life-cycle variable. Control variables include the industry and the year fixed effects, $\varepsilon_{i, t}$ is the residual.

Next, we examine the determinants of board structure across firm life cycle. For the first step, we examine the differences of the determinants using the method of independent sample t-test and non-parametric z-test. For the second step, we test the full sample, and then examine the determinants of board structure at each stage of firm life cycle. The testing model employed in the following is the same as Linck et al. (2008).

We apply the OLS method to regression equation (2) and equation (3) to investigate the determinants of board size and board independence. We apply the LOGISTICS method to regression equation (4) to investigate the determinants of board chair-CEO Duality, because the board chair-CEO duality variable is a binary variable.

$$
\begin{aligned}
\text { Dsize }_{i, t}= & \alpha+\beta_{1} \log \text { Size }+\beta_{2} \log \text { Segments }+\beta_{3} \text { Debt }_{i, t}+\beta_{4} \text { FirmAge }_{i, t} \\
& +\beta_{5} \text { MTB }_{i, t}+\beta_{6} \text { RETSTD }_{i, t}+\text { Controls }_{i, t}+\varepsilon_{i, t} \\
\text { IndpD }_{i, t}= & \alpha+\beta_{1} \log \text { Size }_{i, t}+\beta_{2} \log \text { Segments }_{i, t}+\beta_{3} \text { Debt }_{i, t}+\beta_{4} \text { FirmAge }_{i, t} \\
& +\beta_{5} \text { MTB }_{i, t}+\beta_{6} \text { RETSTD }_{i, t}+\beta_{7} \text { FCF }_{i, t} \\
& +\beta_{8} \text { Perf }_{i, t}+\beta_{9} \text { CeoAge }_{i, t}+\text { Controls }_{i, t}+\varepsilon_{i, t} \\
\text { Dual }_{i, t}= & \alpha+\beta_{1} \log \text { Size }+\beta_{2} \text { MTB }_{i, t}+\beta_{3} \text { RETSTD }_{i, t}+\beta_{4} \text { Perf }_{i, t} \\
& +\beta_{5} \text { CeoAge }_{i, t}+\beta_{6} \text { CeoTenure }_{i, t}+\text { Controls }_{i, t}+\varepsilon_{i, t}
\end{aligned}
$$

Here, Dsize $e_{i, t}$ represents board size for firm i at time t. Similarly, other variables in the equation above represent the corresponding variable for firm i at time $t$, which are all defined in Table 2.

\section{RESULTS}

\section{Regression Results of Board Structure on Firm Life Cycle}

Descriptive statistics. Table 3 presents the whole-sample descriptive statistics of board structure variables. The variable of board size has a mean of 8.641, maximum of 
Table 4. Mean difference tests for board structure variables by firm life-cycle stages

\begin{tabular}{|c|c|c|c|c|c|c|c|c|c|}
\hline \multirow[b]{2}{*}{ Variables } & \multicolumn{3}{|c|}{ Life cycle stage } & \multicolumn{3}{|c|}{ Tvalue } & \multicolumn{3}{|c|}{ Zvalue } \\
\hline & Growth & Maturity & Decline & $G-M$ & $G-D$ & $M-D$ & $G-M$ & $G-D$ & $M-D$ \\
\hline Sample & 1956 & 2232 & 1677 & & & & & & \\
\hline DSize & 8.675 & 8.7 & 8.531 & -0.493 & $2.636^{* * *}$ & $3.088^{* * *}$ & -0.288 & $-2.568^{* *}$ & $-2.857^{* * *}$ \\
\hline Indpd & 0.364 & 0.363 & 0.362 & 0.536 & 0.978 & 0.460 & -1.363 & -1.549 & -0.258 \\
\hline Dual & 0.299 & 0.256 & 0.234 & $3.044^{* * *}$ & $4.532^{* * *}$ & $1.615^{*}$ & $-3.042^{* * *}$ & $-4.491^{* * *}$ & $-1.610^{*}$ \\
\hline
\end{tabular}

Notes: Statistically significant at: ${ }^{*} 10,{ }^{* *} 5$ and ${ }^{* * *} 1$ percent levels, respectively.

18 , minimum of 2 , and standard deviation of 1.677 , indicating a large difference in board size among China's listed POEs. The mean of the proportion of independent directors in the sample is 0.363 , with a standard deviation of 0.065 . The results imply that the proportion of independent directors remains at a stable level in the time horizon. The mean of board chair-CEO duality is 0.264 , showing that for a number of China's listed POEs, their CEO served as the board chair.

China's company law and corporate governance guidelines declare that external independent directors should be one-third of the total board size when the board members are smaller than 19. Our descriptive statistics show a good rate of compliance with the company law and corporate governance guidelines for China's listed POEs.

Mean difference of board structure determinants. We examine the difference between growth and maturity firms, growth and decline firms, maturity and decline firms with a parameters test and a nonparametric test. The results are shown in Table 4. The size of Sample Company's board of directors has a downward trend; the trend differs insignificantly between the growth and the maturity firms, but significantly between the decline, growth, and mature firms.

The proportion of independent directors is relatively steady, and insignificantly different among firm life cycles. Board chair-CEO duality moves downward with firm life cycle, with a significant difference across firm life cycle. This preliminarily result indicates that the board structure is changing as a firm develops. It further reflects that there are certain relationships between the board governance structure and firm life cycle, and the difference exists among different life-cycle stages. All the findings lay the foundation for our next regression testing.

Testing the relationship between board structure and firm life cycle. Table 5 presents the outcome of regressing board structure on firm life cycle. To capture the relative effects of maturity and decline, we omitted the growth variable; as such, three stage variables are dummy variables. Columns (1) and (2) are the outcome regressing board size on firm life cycle, where column (1) shows that the coefficient of maturity variable is negative and insignificant $(\beta=-0.002, p>0.1)$, implying that board 
Table 5. Is board structure influenced by firm life cycle?

\begin{tabular}{|c|c|c|c|c|c|c|}
\hline \multirow[b]{2}{*}{ Variables } & \multicolumn{2}{|c|}{ Dsize } & \multicolumn{2}{|c|}{ Indpd } & \multicolumn{2}{|c|}{ Dual } \\
\hline & 1 & 2 & 3 & 4 & 5 & 6 \\
\hline \multicolumn{7}{|l|}{ Growth } \\
\hline Maturity & $\begin{array}{c}-0.002 \\
(0.047) \\
(p=0.966)\end{array}$ & & $\begin{array}{r}-0.0001 \\
(0.0003) \\
(p=0.724)\end{array}$ & & $\begin{array}{c}-0.038^{* * *} \\
(0.013) \\
(\mathrm{p}=0.005)\end{array}$ & \\
\hline Decline & $\begin{array}{c}-0.175^{* * *} \\
(0.054) \\
(\mathrm{p}=0.001)\end{array}$ & & $\begin{array}{c}-0.0001 \\
(0.0002) \\
(p=0.587)\end{array}$ & & $\begin{array}{l}-0.051^{* * *} \\
(p=0.000)\end{array}$ & \\
\hline Life cycle & & $\begin{array}{c}-0.085^{* * *} \\
(0.027) \\
(\mathrm{p}=0.002)\end{array}$ & & $\begin{array}{c}-0.0001 \\
(0.0002) \\
(p=0.583)\end{array}$ & & $\begin{array}{c}-0.026^{* * *} \\
(0.007) \\
(p=0.000)\end{array}$ \\
\hline Constant & $\begin{array}{c}9.280^{* * *} \\
(0.190) \\
(\mathrm{p}=0.000)\end{array}$ & $\begin{array}{c}9.389^{* * *} \\
(0.195) \\
(\mathrm{p}=0.000)\end{array}$ & $\begin{array}{c}0.250^{* * *} \\
(0.006) \\
(p=0.000)\end{array}$ & $\begin{array}{c}0.251^{* * *} \\
(0.006) \\
(\mathrm{p}=0.000)\end{array}$ & $\begin{array}{c}0.056 \\
(0.050) \\
(p=0.263)\end{array}$ & $\begin{array}{c}0.078 \\
(0.051) \\
(p=0.126)\end{array}$ \\
\hline Industry & Yes & Yes & Yes & yes & yes & yes \\
\hline Year & Yes & Yes & Yes & yes & yes & yes \\
\hline Observations & 5865 & 5865 & 5865 & 5865 & 5865 & 5865 \\
\hline $\operatorname{Adj}-R^{2}$ & 0.036 & 0.036 & 0.163 & 0.163 & 0.041 & 0.041 \\
\hline $\mathrm{F}$ & $9.839^{* * *}$ & $10.097^{* * *}$ & $46.601^{* * *}$ & $48.551^{* * *}$ & $10.996^{* * *}$ & $11.407^{* * *}$ \\
\hline
\end{tabular}

Notes: Standard errors are in parentheses, ${ }^{*} p<0.1 ;{ }^{* *} p<0.05 ;{ }^{* * *} p<0.01$ (two-tailed)

size is insignificantly smaller at the maturity stage than at the growth stage; while the coefficients of decline variable are significantly negative $(\beta=-0.175, p<$ 0.01 ), indicating that board size is significantly smaller at the decline stage than at the growth stage. Moreover, the coefficients of life-cycle variable in column (2) are significantly negative $(\beta=-0.085, p<0.01)$, implying that board size is decreasing in the whole firm life cycle. Hypothesis la (board of directors' advising function) is supported. Columns (3) and (4) show the outcomes of regressing board independence on firm life cycle. The results show that board independence is not significantly different between the maturity/decline stages and the growth stage $(\beta=-0.0001, p>0.1)$. The results imply that the board independence of China's listed POEs is stable at a certain level. Therefore, hypothesis $1 \mathrm{~b}$ is not supported. Columns (5) and (6) show the outcomes of regressing board chair-CEO duality on firm life cycle, where the outcomes of column (5) show that the coefficient of maturity variable is negatively significant $(\beta=-0.038, p<0.01)$, indicating that the change of the duality is more separated at the maturity stage than at the growth stage. The coefficient of decline variable is significantly negative $(\beta=-0.051, p<$ 0.01 ), indicating that the duality is also more separated at the maturity stage than at the growth stage. Furthermore, the coefficient of life cycle variable in column (6) is significantly negative $(\beta=-0.026, p<0.01)$, which is almost in accordance with the prediction of the separation of board chair-CEO duality in the whole firm life cycle (hypothesis 1c). 
Given our findings, an observation about the board structure of China's listed POEs evolving with firm life cycle can be made as follows: board size shrinks during the whole life cycle, and the board chair-CEO duality will separate, while board independence remains almost unchanged. It reflects our hypothesis that the boards of China's listed POEs are mostly driven by consideration of the resources and advising brought by directors; while the monitoring function of the board of directors is less taken into account. The adjustment of board independence occurs only to comply with Chinese law enforcement, because the number of independent directors does not increase with the potential severity of agency problem when a firm matures; this may contribute to the failure of a board to monitor the managerial agency of the firm.

\section{Regression Results of Determinants of Board Structure}

Mean difference tests of board structure determinants. Table 6 presents the descriptive statistics of the determinants of boards of directors and their differences in testing outcomes. Board size moves downward with a significant difference between every two stages of firm life cycle. The variable of business segments shows an upward trend, with a significant difference between the growth and maturity stages and between the growth and decline stages. Debt ratio first decreases and then increases, and it is significantly different between the growth and decline stages, and between the maturity and decline stages. Firm age grows larger with a significant difference among every two life-cycle stages. The findings imply that our indicator of a firm's life cycle classification is effective. The firm's free cash flow increases through its life cycle, with an insignificant difference between the growth decline stages. The variable of market-to-book ratio inclines, with a significant difference among every two life cycle stages. The variable of return is more volatile across life cycle, with an insignificant difference over firm life cycle. The difference of firm performance becomes small between the growth and decline stages and the maturity and decline stages with a significant difference. CEO age goes upward through life cycle, with an insignificant difference. CEO tenure is shorter through life cycle, with a significant difference between the growth stage and the decline stage. The variable of managerial stock holdings demonstrates an invert $U$ shape with an insignificant difference among every two life-cycle stages, while the value of the difference of institutional stock holdings is small but with a significant difference among every two-firm life-cycle stages. From the above results, we preliminarily summarize that the effects of board structure change with firm life cycle, and most of the variables are with significant differences over firm life-cycle stages.

Regression test of the determinants of board structure over firm life cycle stages. Table 7 presents the regression outcomes of the determinants of board structure across firm life cycle. For the whole sample, board size is significantly and positively related to firm size and negatively related to firm age, while other variables have 
Table 6. Mean difference tests of determinants of board structure by firm life-cycle stages

\begin{tabular}{|c|c|c|c|c|c|c|c|c|c|}
\hline \multirow[b]{2}{*}{ Variable } & \multicolumn{3}{|c|}{ Life cycle } & \multicolumn{3}{|c|}{ T Value } & \multicolumn{3}{|c|}{ Z Value } \\
\hline & Growth & Maturity & Decline & $G-M$ & $G-D$ & $M-D$ & $G-M$ & $G-D$ & $M-D$ \\
\hline Sample & 1956 & 2232 & 1677 & & & & & & \\
\hline Size & 19.327 & 18.994 & 18.751 & $2.488^{* *}$ & $4.077^{* * *}$ & $1.700^{*}$ & $-3.390^{* * *}$ & $-5.899^{* * *}$ & $-2.672^{* * *}$ \\
\hline Segments & 2.783 & 2.925 & 2.901 & $-2.031^{* *}$ & $-1.794^{*}$ & 0.348 & $-3.238^{* * *}$ & $-4.940^{* * *}$ & $-1.736^{*}$ \\
\hline Debt & 0.402 & 0.389 & 0.513 & 0.513 & $-2.812^{* * *}$ & $-2.691^{* * *}$ & -0.519 & $-2.207^{* *}$ & $-1.716^{*}$ \\
\hline Firmage & 6.057 & 8.135 & 10.251 & $-14.113^{* * *}$ & $-27.371^{* * *}$ & $-13.025^{* * *}$ & $-13.905^{* * *}$ & $-25.623^{* * *}$ & $-13.172^{* * *}$ \\
\hline FCF & -0.011 & -0.021 & 0.000 & 0.424 & $-1.855^{*}$ & -0.876 & $-4.318^{* * *}$ & $-4.502^{* * *}$ & -0.430 \\
\hline МТВ & 1.991 & 2.168 & 2.601 & $-2.422^{* *}$ & $-2.544^{* *}$ & $-1.751^{*}$ & -0.300 & $-1.800^{*}$ & -1.479 \\
\hline RETSTD & 0.129 & 0.134 & 0.135 & -1.512 & $-2.796^{* *}$ & -0.399 & -0.844 & $-3.882^{* * *}$ & $-3.090^{* * *}$ \\
\hline Perf & 0.091 & 0.070 & 0.067 & 1.237 & 1.339 & 0.456 & $-3.638^{* * *}$ & $-9.074^{* * *}$ & $-5.474^{* * *}$ \\
\hline CEOAge & 46.233 & 46.434 & 46.445 & -0.954 & -0.947 & -0.050 & -1.101 & -0.690 & -0.297 \\
\hline CEOTenure & 3.028 & 2.959 & 2.844 & 0.863 & $2.229^{*}$ & 1.386 & $-1.692^{*}$ & $-2.873^{* * *}$ & -1.178 \\
\hline MStkHd & 0.257 & 0.257 & 0.249 & -0.004 & 0.653 & 0.640 & $-2.742^{* * *}$ & $-6.505^{* * *}$ & $-3.988^{* * *}$ \\
\hline LgStkHd & 4.703 & 2.450 & 1.381 & $8.231^{* * *}$ & $13.171^{* * *}$ & $5.885^{* * *}$ & $-7.461^{* * *}$ & $-13.705^{* * *}$ & $-6.998^{* * *}$ \\
\hline
\end{tabular}

Notes: Standard errors are in parentheses, ${ }^{*} p<0.1 ;{ }^{* *} p<0.05 ;{ }^{* * *} p<0.01$ (two-tailed) 
Table 7. Determinants of board structure at different stages of firm life cycle

\begin{tabular}{|c|c|c|c|c|c|c|c|c|c|c|c|c|}
\hline \multirow[b]{2}{*}{ Variable } & \multicolumn{3}{|c|}{ All sample } & \multicolumn{3}{|c|}{ Sub-sample of Growth } & \multicolumn{3}{|c|}{ Sub-sample of Maturity } & \multicolumn{3}{|c|}{ Sub-sample of Decline } \\
\hline & Dsizes & Indpd & Dual & Dsize & Indpd & Dual & Dsize & Indpd & Dual & Dsize & Indpd & Dual \\
\hline \multirow{4}{*}{ Size } & (1) & (2) & (3) & (1) & (2) & (3) & (1) & (2) & (3) & (1) & (2) & (3) \\
\hline & $0.365^{* * *}$ & $0.002^{* *}$ & $-0.215^{* * *}$ & $0.405^{* * *}$ & -0.001 & $-0.270^{* * *}$ & $0.468^{* * *}$ & $0.003^{* *}$ & $-0.261^{* * *}$ & $0.206^{* * *}$ & -0.0002 & $-0.228^{* * *}$ \\
\hline & $(0.023)$ & $(0.001)$ & $(0.033)$ & $(0.042)$ & $(0.001)$ & $(0.061)$ & $(0.041)$ & $(0.0014)$ & $(0.062)$ & $(0.041)$ & $(0.001)$ & $(0.061)$ \\
\hline & $(\mathrm{p}=0.000)$ & $(\mathrm{p}=0.047)$ & $(\mathrm{p}=0.000)$ & $(\mathrm{p}=0.000)$ & $(\mathrm{p}=0.271)$ & $(\mathrm{p}=0.000)$ & $(\mathrm{p}=0.000)$ & $(\mathrm{p}=0.040)$ & $(\mathrm{p}=0.000)$ & $(\mathrm{p}=0.000)$ & $(\mathrm{p}=0.859)$ & $(\mathrm{p}=0.0002)$ \\
\hline \multirow[t]{3}{*}{ Segments } & -0.005 & -0.001 & & -0.015 & -0.0004 & & -0.017 & -0.0003 & & 0.028 & $-0.001^{* *}$ & \\
\hline & $(0.011)$ & $(0.0004)$ & & $(0.018)$ & $(0.0006)$ & & $(0.018)$ & $(0.0006)$ & & $(0.024)$ & $(0.0006)$ & \\
\hline & $(\mathrm{p}=0.686)$ & $(\mathrm{p}=0.142)$ & & $(\mathrm{p}=0.421)$ & $(\mathrm{p}=0.514)$ & & $(\mathrm{p}=0.335)$ & $(\mathrm{p}=0.626)$ & & $(\mathrm{p}=0.232)$ & $(\mathrm{p}=0.076)$ & \\
\hline \multirow[t]{3}{*}{ Debt } & 0.033 & $-0.003^{* * *}$ & & 0.140 & 0.001 & & $0.097^{* *}$ & -0.002 & & -0.003 & $0.005^{* * *}$ & \\
\hline & $(0.022)$ & $(0.001)$ & & $(0.136)$ & $(0.004)$ & & $(0.042)$ & $(0.003)$ & & $(0.041)$ & $(0.0016)$ & \\
\hline & $(\mathrm{p}=0.134)$ & $(\mathrm{p}=0.002)$ & & $(\mathrm{p}=0.301)$ & $(\mathrm{p}=0.794)$ & & $(\mathrm{p}=0.023)$ & $(\mathrm{p}=0.478)$ & & $(\mathrm{p}=0.951)$ & $(\mathrm{p}=0.001)$ & \\
\hline \multirow[t]{3}{*}{ FirmAge } & $-0.012^{* *}$ & 0.000 & & 0.007 & -0.00048 & & $-0.017^{* *}$ & -0.0002 & & $-0.024^{* *}$ & 0.0005 & \\
\hline & $(0.005)$ & $(0.0002)$ & & $(0.010)$ & $(0.0003)$ & & (0.009) & (0.0003) & & $(0.009)$ & $(0.0003)$ & \\
\hline & $(\mathrm{p}=0.014)$ & $(\mathrm{p}=0.543)$ & & $(\mathrm{p}=0.484)$ & $(\mathrm{p}=0.133)$ & & $(\mathrm{p}=0.046)$ & $(\mathrm{p}=0.434)$ & & $(\mathrm{p}=0.010)$ & $(\mathrm{p}=0.125)$ & \\
\hline \multirow[t]{3}{*}{ МТВ } & 0.005 & 0.000 & -0.011 & 0.020 & -0.0001 & -0.037 & 0.035 & 0.001 & -0.055 & 0.005 & 0.001 & -0.008 \\
\hline & $(0.004)$ & $(0.0002)$ & $(0.008)$ & $(0.032)$ & $(0.001)$ & $(0.045)$ & $(0.023)$ & $(0.0007)$ & $(0.035)$ & $(0.007)$ & $(0.001)$ & $(0.007)$ \\
\hline & $(\mathrm{p}=0.236)$ & $(\mathrm{p}=0.989)$ & $(\mathrm{p}=0.192)$ & $(\mathrm{p}=0.529)$ & $(\mathrm{p}=0.919)$ & $(\mathrm{p}=0.405)$ & $(\mathrm{p}=0.261)$ & $(\mathrm{p}=0.203)$ & $(\mathrm{p}=0.118)$ & $(\mathrm{p}=0.441)$ & $(\mathrm{p}=0.298)$ & $(\mathrm{p}=0.261)$ \\
\hline \multirow[t]{3}{*}{ RETSTD } & -0.329 & 0.004 & 0.468 & $-1.061^{*}$ & -0.003 & 0.098 & -0.006 & -0.002 & 0.456 & -1.501 & 0.046 & $1.679^{*}$ \\
\hline & $(0.224)$ & $(0.008)$ & $(0.301)$ & $(0.560)$ & $(0.019)$ & $(0.930)$ & $(0.273)$ & $(0.009)$ & $(0.348)$ & (1.088) & $(0.041)$ & $(0.881)$ \\
\hline & $(\mathrm{p}=0.142)$ & $(\mathrm{p}=0.558)$ & $(\mathrm{p}=0.120)$ & $(\mathrm{p}=0.058)$ & $(\mathrm{p}=0.865)$ & $(\mathrm{p}=0.916)$ & $(\mathrm{p}=0.982)$ & $(\mathrm{p}=0.826)$ & $(\mathrm{p}=0.189)$ & $(\mathrm{p}=0.187)$ & $(\mathrm{p}=0.303)$ & $(\mathrm{p}=0.057)$ \\
\hline \multirow[t]{3}{*}{ FCF } & & $0.004^{* *}$ & & & -0.003 & & & 0.005 & & & -0.004 & \\
\hline & & $(0.002)$ & & & $(0.010)$ & & & $(0.004)$ & & & $(0.007)$ & \\
\hline & & $(\mathrm{p}=0.033)$ & & & $(\mathrm{p}=0.765)$ & & & $(\mathrm{p}=0.254)$ & & & $(\mathrm{p}=0.552)$ & \\
\hline \multirow[t]{3}{*}{ Perf } & & 0.002 & 0.015 & & 0.002 & -0.028 & & $-0.022^{*}$ & 0.240 & & -0.007 & 0.093 \\
\hline & & $(0.002)$ & $(0.084)$ & & $(0.002)$ & $(0.172)$ & & $(-0.012)$ & $(0.526)$ & & $(0.007)$ & $(0.243)$ \\
\hline & & $(\mathrm{p}=0.313)$ & $(\mathrm{p}=0.855)$ & & $(\mathrm{p}=0.163)$ & $(\mathrm{p}=0.872)$ & & $(\mathrm{p}=0.078)$ & $(\mathrm{p}=0.648)$ & & $(\mathrm{p}=0.288)$ & $(\mathrm{p}=0.702)$ \\
\hline \multirow[t]{3}{*}{ CEOAge } & & 0.000 & $0.074^{* * *}$ & & -0.000 & $0.084^{* * *}$ & & 0.0001 & $0.080^{* * *}$ & & 0.000 & $0.066^{* * *}$ \\
\hline & & $(0.0001)$ & $(0005)$ & & $(0.0002)$ & $(0.008)$ & & $(0.0002)$ & $(0.009)$ & & $(0.0002)$ & $(0.009)$ \\
\hline & & $(\mathrm{p}=0.799)$ & $(p=0.000)$ & & $(\mathrm{p}=0.639)$ & $(\mathrm{p}=0.000)$ & & $(p=0.488)$ & $(\mathrm{p}=0.000)$ & & $(\mathrm{p}=0.899)$ & $(\mathrm{p}=0.000)$ \\
\hline
\end{tabular}


Table 7. Continued

\begin{tabular}{|c|c|c|c|c|c|c|c|c|c|c|c|c|}
\hline \multirow[b]{2}{*}{ Variable } & \multicolumn{3}{|c|}{ All sample } & \multicolumn{3}{|c|}{ Sub-sample of Growth } & \multicolumn{3}{|c|}{ Sub-sample of Maturity } & \multicolumn{3}{|c|}{ Sub-sample of Decline } \\
\hline & Dsizes & Indpd & Dual & Dsize & Indpd & Dual & Dsize & Indpd & Dual & Dsize & Indpd & Dual \\
\hline CEOTenure & & & $\begin{array}{c}0.080^{* *_{\mathrm{v}}} \\
(0.016) \\
(\mathrm{p}=0.000)\end{array}$ & & & $\begin{array}{c}0.085^{* * *} \\
(0.027) \\
(\mathrm{p}=0.001)\end{array}$ & & & $\begin{array}{c}0.097^{* * *} \\
(0.028) \\
(\mathrm{p}=0.0005)\end{array}$ & & & $\begin{array}{c}0.081^{* * *} \\
(0.031) \\
(\mathrm{p}=0.009)\end{array}$ \\
\hline MStkHd & $\begin{array}{c}0.025 \\
(0.079) \\
(\mathrm{p}=0.756)\end{array}$ & $\begin{array}{l}0.002^{*} \\
(0.003) \\
(\mathrm{p}=0.095)\end{array}$ & & $\begin{array}{c}0.023 \\
(0.128) \\
(\mathrm{p}=0.857)\end{array}$ & $\begin{array}{c}0.006^{*} \\
(0.003) \\
(\mathrm{p}=0.045)\end{array}$ & & $\begin{array}{c}0.089 \\
(0.134) \\
(\mathrm{p}=0.506)\end{array}$ & $\begin{array}{c}0.003 \\
(0.004) \\
(\mathrm{p}=0.488)\end{array}$ & & $\begin{array}{c}-0.008 \\
(0.160) \\
(\mathrm{p}=0.960)\end{array}$ & $\begin{array}{c}-0.003^{*} \\
(0.0016) \\
(\mathrm{p}=0.085)\end{array}$ & \\
\hline LgStkHd & $\begin{array}{c}-0.003 \\
(0.003) \\
(\mathrm{p}=0.373)\end{array}$ & $\begin{array}{c}0.000 \\
(0.0001) \\
(\mathrm{p}=0.588)\end{array}$ & & $\begin{array}{c}-0.006 \\
(0.004) \\
(\mathrm{p}=0.131)\end{array}$ & $\begin{array}{c}0.0003 \\
(0.0002) \\
(\mathrm{p}=0.000)\end{array}$ & & $\begin{array}{c}-0.001 \\
(0.004) \\
(\mathrm{p}=0.816)\end{array}$ & $\begin{array}{c}0.000 \\
(0.090) \\
(\mathrm{p}=0.928)\end{array}$ & & $\begin{array}{c}0.010 \\
(0.010) \\
(\mathrm{p}=0.295)\end{array}$ & $\begin{array}{c}0.000 \\
(0.0003) \\
(\mathrm{p}=0.989)\end{array}$ & \\
\hline Constant & $\begin{array}{c}5.120^{* * *} \\
(0.324) \\
(\mathrm{p}=0.000)\end{array}$ & $\begin{array}{l}0.270^{* * *} \\
(0.012) \\
(\mathrm{p}=0.000)\end{array}$ & $\begin{array}{c}-3.679^{* * *} \\
(0.559) \\
(\mathrm{p}=0.000)\end{array}$ & $\begin{array}{c}5.226^{* * *} \\
(0.599) \\
(\mathrm{p}=0.000)\end{array}$ & $\begin{array}{c}0.276^{* * *} \\
(0.021) \\
(\mathrm{p}=0.000)\end{array}$ & $\begin{array}{c}-2.823^{* * *} \\
(0.976) \\
(\mathrm{p}=0.004)\end{array}$ & $\begin{array}{c}3.518^{* * *} \\
(0.571) \\
(\mathrm{p}=0.000)\end{array}$ & $\begin{array}{l}0.277^{* * *} \\
(0.021) \\
(\mathrm{p}=0.000)\end{array}$ & $\begin{array}{c}-3.813^{* * *} \\
(1.0622) \\
(\mathrm{p}=0.0003)\end{array}$ & $\begin{array}{c}6.743^{* * *} \\
(0.585) \\
(\mathrm{p}=0.000)\end{array}$ & $\begin{array}{c}0.249^{* * *} \\
(0.022) \\
(\mathrm{p}=0.000)\end{array}$ & $\begin{array}{c}-3.779^{* * *} \\
(1.049) \\
(\mathrm{p}=0.0003)\end{array}$ \\
\hline Industry & Yes & Yes & Yes & Yes & Yes & Yes & Yes & Yes & Yes & Yes & Yes & Yes \\
\hline Year & Yes & Yes & Yes & Yes & Yes & Yes & Yes & Yes & Yes & Yes & Yes & Yes \\
\hline Observations & 5865 & 5865 & 5865 & 1956 & 1956 & 1956 & 2232 & 2232 & 2232 & 1677 & 1677 & 1677 \\
\hline Adj/Pseudo R ${ }^{2}$ & 0.078 & 0.165 & 0.099 & 0.096 & 0.159 & 0.121 & 0.096 & 0.155 & 0.116 & 0.056 & 0.198 & 0.096 \\
\hline F/LR stat & 17.013 & 35.180 & 6165.657 & 8.070 & 12.408 & 2243.104 & 8.136 & 12.161 & 2106.713 & 4.324 & 13.539 & 1709.673 \\
\hline
\end{tabular}

Notes: Standard errors are in parentheses; ${ }^{*} p<0.1 ;{ }^{* *} p<0.05 ;{ }^{* * *} p<0.01$ (two-tailed). As dual is tested by logistic method, so its following test value for independent variables is wald test value. 
no significant effect on board size. Board independence is significantly affected by firm size, debt ratio, and free cash flow, which accord with the hypothesis expecting that board directors can bring the benefits of monitoring and advising for a firm. However, the hypothesis predicting a relationship between the costs of monitoring and advising of adding board size/independence is not fully supported; this is partially because the segments of China's listed POEs have weak effects on board structure, indicating that the adjustment cost of board structure is not considered when adjusting board structure. Board chair-CEO duality is significantly and positively related to $\mathrm{CEO}$ age and CEO tenure, and significantly and negatively related to firm size. The results, implying a strong CEO authority in China, could be additional evidence for the inefficiency of China's corporate governance.

We further run a regression test for subsamples classified by firm life cycles, and the outcome shows some differences. As for the subsample of growth stage, board size is significantly and positively related to firm size $(\beta=0.405, p<0.01)$. Board independence is only positively and significantly affected by the variable of manager stock holdings $(\beta=0.006, p<0.05)$. The result reveals that increasing board members will bring benefits to a firm by releasing resource constraints; but manager stock holdings will enhance board independence of the firm, supporting hypothesis $2 \mathrm{a}$, while not supporting hypotheses $2 \mathrm{a} 2$. Board chair-CEO duality is significantly and positively related to $\mathrm{CEO}$ age $(\beta=0.084, p<0.01)$ and CEO tenure $(\beta=0.085, p<0.01)$, while significantly and negatively related to firm size $(\beta=-0.027, p<0.01)$. The results related to CEOs indicate that it is beneficial for small companies having a centralized leadership structure. With the CEO's influence and power increasing, the costs from separation of board chair and CEO go up, so the company also tends to have a centralized leadership structure, consistent with the predictions of hypothesis 2a3 and hypothesis 2a4.

As for the subsample of maturity stage, board size is significantly and positively related to firm size $(\beta=0.468, p<0.01)$ and debt ratio $(\beta=0.097, p<0.05)$, while significantly and negatively related to firm age $(\beta=-0.017, p<0.05)$. Board independence is positively affected by firm size $(\beta=0.003, p<0.05)$, and negatively affected by a firm's past performance $(\beta=-0.022, p<0.1)$. These findings indicate that the benefits bringing by board of directors to defend against agency problems are also attractive for firms. We also find that board size is smaller with firm age. Therefore, hypothesis $2 \mathrm{bl}$ is supported, while hypothesis $2 \mathrm{~b} 2$ is not supported. Board chair-CEO duality is significantly and positively related to CEO age $(\beta=0.080, p<0.01)$ and $\mathrm{CEO}$ tenure $(\beta=0.097, p<0.01)$, while significantly and negatively related to firm size $(\beta=-0.261, p<0.01)$. The findings indicate that it is beneficial for a company with an increase in the CEO's power having a decentralized leadership structure, because the costs of separation of board chair and CEO goes up. Large companies tend to have a separated leadership structure, because the benefits of separation of board chair and CEO increase. Hypotheses $2 \mathrm{~b} 3$ and hypothesis $2 \mathrm{~b} 4$ are supported. 
As for the decline stage subsample, board size is significantly and positively related to firm size $(\beta=0.206, p<0.01)$, while significantly and negatively related to firm age $(\beta=-0.024, p<0.05)$. Board independence is significantly and positively related to debt ratio $(\beta=0.005, p<0.01)$, while significantly and negatively related to firm segments $(\beta=-0.001, p<0.05)$ and manager stock holdings $(\beta=-0.003, p<0.1)$. The results support hypotheses $2 \mathrm{c} 1$ and $2 \mathrm{c} 3$. The findings show that the benefits of board function resulting both from releasing resource constraints and from defending against the agency problem are also significant at the decline stage. It is found that firms at the decline stage are associated with a few independent board members. The finding may be explained by the fact that most declining POEs in China strive to develop new business, and therefore they tend to appoint fewer external directors. Board chair-CEO duality is significantly and negatively related to firm size $(\beta=-0.228, p<0.01)$, and significantly and positively related to volatility of stock return $(\beta=1.679, p<$ $0.1)$, CEO age $(\beta=0.066, p<0.01)$ and CEO tenure $(\beta=0.081, p<0.01)$. The results support hypotheses $2 \mathrm{c} 1$ and $2 \mathrm{c} 2$. A company with high information asymmetry tends to have a centralized leadership structure, and the company with a centralized leadership structure is also driven by $\mathrm{CEO}$ influence, as the costs of the separation of board chair and CEO go up. Large companies tend to have a separated leadership structure, because the benefits of separation of board chair and CEO increase with size. Hypotheses $2 \mathrm{~b} 3$ and $2 \mathrm{~b} 4$ are supported.

Our findings indicate that the hypothesis of benefits of board of directors' advising and monitoring with different drivers is supported at the growth stage and the maturity stage of firm life cycle, while the hypothesis of the costs of monitoring and advising by the board is not supported. The hypothesis about board chairCEO duality with different drivers is supported at all three stages of firm life cycle. All the results demonstrate that the impacts of board structure are changing at different stages of firm life cycle. Therefore, it is critical to pay close attention to firm life-cycle characteristics in adjusting and improving board structure.

\section{Robustness Tests}

Endogenous test of board structure. There exists potential endogeneity in board structure determinants. To address the potential endogenous problem, we first use a two-stages least squares method to test the determinants of board size and board independence (see appendix table 1A), and find that the results of the main variables in the test are consistent with the previous results. Second, given the continuity of board structure, we examine the determinants of board structure controlling for lag variables (see appendix table 1B), the results are also highly consistent with the previous conclusion.

Sensitivity test of the classification indicator of firm life cycle. We have tested the sensitivity of the classification indicator of firm life cycle. Since there is no conclusive measure 
to capture firm life cycle in prior literature, we first test the data according to the life cycle classification from Anthony and Ramesh (1992) and Hribar and Yehuda (2007), by employing the composite scoring indicators of dividend payments, sales growth, capital expenditure and firm age to classify firm life cycle stages. We then use their classifications to examine the relationship between board structure and firm life cycle. The results are consistent with our previous conclusion (see Appendix II, Table 2).

\section{DISGUSSION}

From a dynamic perspective, we have investigated how board structure evolves across firm life cycle based on agency theory and resource dependency theory. The results show that board size is significantly and negatively associated with firm life cycle, and a one-unit increase in firm life cycle will lead to a decrease of 0.085 unit in board size. Board chair and CEO duality is also significantly and negatively associated with firm life cycle, and a one-unit increase in firm life cycle will lead to a 0.026 unit decrease in board chair and CEO duality. However, board independence is insignificantly and negatively associated with firm life cycle. Consistent with resource dependency theory, the above evidence supports hypotheses $1 \mathrm{a}$ and 1c, and does not support hypothesis 1b. Our findings suggest that board size and board chair and CEO duality would be significantly affected by firm life cycle. At the same time, the complex indicator of life cycle does not explain much deviation of board size and board chair and CEO duality. One of the reasons could be that board structure is different for individual firms, and the structure may be largely determined by firm characteristics, as evidenced by a set of literature (Boone \& Field, 2007; Coles et al., 2008; Lehn et al., 2009; Linck et al., 2008; Wintoki et al., 2012). In terms of board independence, because the listed firms in China are required to meet the corporate law of maintaining one-third of board members as independent directors, the space left for their self-adjusting in board structure is limited in the weaker external corporate governance in China. This is the reason why board independence remains almost static across firm life cycle.

The results further show that board size and independence are significantly and positively associated with the benefits of adding directors across firm life cycle, supporting hypotheses 2-a1, 2-bl and 2-c1. And at the growth stage, a one-unit increase in the indicator of benefits (firm size) will lead to an increase of 0.405 units in board size. At the maturity stage, a one-unit increase in the indicator of benefits (firm size) will lead to an increase of 0.468 unit in board size; a one-unit increase in another indicator of benefits (firm debt) will lead to 0.097 unit increase in board size, and a one-unit increase in the indicator of benefits (firm size) will lead to 0.003 unit increase in board independence. At the decline stage, a one-unit increase in the indicator of benefits (firm size) will lead to an increase of 0.206 unit in board size, a one-unit increase in another indicator of benefits (firm debt) will lead to an increase 
of 0.005 unit in board independence. Meanwhile, the results also show that board size/board independence is almost insignificantly and negatively associated with the costs from adding directors, not supporting hypotheses 2-a2, 2-b2 and 2-c2. At the growth stage, a one-unit increase in the indicator of costs (RETSTD) will lead to -1.061 unit decrease in board size. At the maturity and decline stages, this indicator of costs (RETSTD) is not significant. Further, the indicator of costs (RETSTD) is not significantly related with board independence, and another indicator of costs (MTB) is not significant through all stages of firm life cycle for neither board size nor board independence. These null results could be explained by China's institutional environments and POEs' characteristics. The POEs in China still suffer an inferior status in accessing external resources. Therefore, the firms in this setting may pay more attention to whether they can obtain access to resources, while caring less about the related costs. The results above suggest that the adjustment of board size and independence for China's POEs is mainly driven by the benefits rather than the costs of adjusting directors across firm life cycle, no matter whether such benefits and costs are mainly related to releasing resource constraints or to defending against agency problems at different stages of a firm.

As for board chair and CEO duality, the results suggest that board chair and CEO duality is significantly and positively associated with the costs of the separation of board chair and CEO, and significantly and negatively associated with the benefits of the separation of board chair and CEO. The findings support hypotheses 2-a3, 2-a4, 2-b3, 2b4, 2-c3, and 2-c4. At the growth stage, a one-unit increase in the indicator of benefits (firm size) will lead to a decrease of 0.270 units in board chair and CEO duality; a one-unit increase in the indicator of costs (CEO age) will lead to an increase of 0.084 unit in board chair and CEO duality; and a one-unit increase in the indicator of costs (CEO tenure) will lead to an increase of 0.085 unit in board chair and CEO duality. At the maturity stage, a one-unit increase in the indicator of benefits (firm size) will lead to a decrease of 0.261 units in board chair and CEO duality; a one-unit increase in the indicator of costs (CEO age) will lead to an increase of 0.080 units in board chair and CEO duality; and a one-unit increase in the indicator of costs (CEO tenure) will lead to an increase of 0.097 unit in board chair and CEO duality. At the decline stage, a one-unit increase in the indicator of benefits (firm size) will lead to a decrease of 0.228 units in board chair and CEO duality; a one-unit increase in the indicator of costs (CEO age) will lead to 0.066 unit increase in board chair and CEO duality; a one-unit increase in the indicator of costs (CEO tenure) will lead to 0.081unit increase in board chair and CEO duality; and a one-unit increase in the indicator of costs (RETSTD) will lead to 1.679 unit increase in board chair and CEO duality. The results imply that it is beneficial for small companies to have a centralized leadership structure through all stages of firm life cycle. With the increase of a CEO's influence and power, the costs entailed in separation of board chair and CEO increase. That's why small companies prefer to have a centralized leadership structure. 


\section{Contributions and Implications}

Employing agency theory and resource dependency theory, this article has investigated board structure based on a dynamic view of firm life cycle. Hillman and Dalziel (2003) study board formation at each stage of firm life cycle. While our framework is consistent with their pioneering work, we have further analyzed board structure dynamics with a focus on the adjustments driven by changing agency problems and desired resources from board formation. Our findings have enriched the literature on board structure evolution through firm life cycle.

Moreover, because this study dynamically considers the board structure of POEs as a response both internally and externally to environmental dynamism in the context of China, our analysis of board structure greatly mediates the debate on whether a larger or more independent board is good or bad.

The results on board efficiency in existing literature (Adams \& Ferreira, 2007; Coles et al., 2008; Fama \& Jensen, 1983; Jensen, 1993; Lipton \& Lorsch, 1992; Raheja, 2005) are mixed. By introducing the new factor of firm life cycle, we have shown that board structure changes with firm life cycle and board structure determinants also differ at various firm stages. Our findings shed light on the questions about board evolution and about mechanisms to enhance board efficiency.

With a newly developed proxy for firm life cycle, we have also contributed to current literature on the measure of firm life cycle. Prior studies propose some proxies to capture firm life cycle (Anthony \& Ramesh, 1992; Bens, Nagar, \& Wong, 2002; DeAngelo et al., 2006; Hribar \& Yehuda, 2007), but the proxies are purely applied to developed economies. To our best knowledge, we are the first to take a comprehensive account of the industry features and firm characteristics for companies in an emerging market that, due to limited government control, are not comparable to US firms, and to construct a composite score to classify firm life-cycle stages. The newly developed measure of life cycle has engaged Anthony and Ramesh (1992)'s measure into emerging economies.

Our findings have practical importance for both managerial practitioners and policy makers. First, our study demonstrates that board characteristics such as size and independence are associated with firm resources and agency conflicts. The findings suggest that firms need to adjust board structure to a proper level in a timely manner to improve their competition. Second, since the optimal board structure dynamically varies across firm life cycle, supervisory authorities should not simply require one corporate governance structure for all listed companies in China. The regulator needs to set up compulsory governance principles and allow the firms to adjust their board structure independently in response to their development at different life-cycle stages. 


\section{Limitations and Future Research Directions}

This research has a few limitations. We have investigated how firm life cycle affects board structure, and demonstrated that the changing of board structure should match firm life cycle. However, we have not further identified the optimal board structure in each stage of firm life cycle. How a board approaches the optimal structure is also beyond the scope of our study. The effectiveness due to board structure adjustment across firm life cycle appears to be a future direction.

Second, our study has focused solely on the listed POEs in China, while the stateowned enterprises are still a dominant party in China. The state-owned enterprises are characterized by a special corporate governance system with significant government influence. Investigation of the relationship between their life cycle and board structure dynamics serves an important complement to understand corporate governance in emerging markets.

Third, we have presented hypotheses for board monitoring and advisory roles and employed a set of variables suggested by prior literature (Booth \& Deli, 1999; Bushman et al., 2004; Fama \& Jensen, 1983; Gaver \& Gaver, 1993; Smith \& Watts, 1992) to proxy for the benefits or costs associated with the two roles. We acknowledge that an empirical analysis with direct measures of the board roles would provide additional support for our theoretical construct.

Finally, we have constructed an improved method to classify firm life cycle based on prior literature (Anthony \& Ramesh, 1992; DeAngelo et al., 2006; Hribar \& Yehuda, 2007). While employing the new life cycle measure to China's firms between 2002 and 2014, we have demonstrated that it is a highly effective measure to capture firm life cycle in developed countries is unexplored, though study of developed countries such as the US is out of scope of our article.

\section{GONGLUSION}

Current studies on board structure mostly evaluate governance functions from a static perspective, while ignoring the board's dynamic improvement and adjustment with firm life cycle. In this article, we have constructed a new indicator to classify firm life cycle and investigated board structure evolution with firm life cycle. We have found that the board size of China's listed POEs declines through the three stages of firm life cycle, that the board chair-CEO duality has a trend of separation, and that board independence stays stable. We have also provided evidence that the hypothesis regarding benefits of board members with different drivers is accepted through the three stages of firm life cycle, while the hypothesis of costs is not supported. The influence of CEO power on board chair-CEO duality is determined by the benefits, and costs of the separation of board chair and CEO are supported at all stages of firms' life cycle. This study reveals that the adjustment of boards of directors of China's listed POEs is largely driven by additional resources 
from new independent directors. This article also suggests that board structure determinants are dynamic through different stages of firm life cycle. It is beneficial for firms to improve board efficiency by establishing proper board structure at different firm stages.

\section{NOTES}

We are thankful for the comments from the editor and reviewers, and we also thank the participants at Corporate Governance Session of the China International Conference in Finance in Chongqing 2012 for their helpful comments; and we acknowledge the financial support for the project of Shanghai Social Science Fund (for the Youth 2012EJB003) and National Social Science Fund of China (for the Youth 13CGL048).

[1] According to the Guideline for the Establishment of the Independent Director System in Listed Firms issued in 2001 by the China Securities Regulatory Commission (CSRC), boards of directors in China consist of two types of directors: independent/outside directors and non-independent/insider directors. Outside directors are usually called independent directors, as they are invited from outside companies with no affiliation with the hiring companies.

[2] In general, if a firm is suffering a severe decline, it will be eventually delisted from the stock market. As a result, it is not a surprise to observe a fewer firms at the decline stage compared with the firms at other stages.

\section{APPENDIX I. ENDOGENSOUS TESTS}

\section{Appendix 1A. Two-Stage Regression Test}

This table reports results from regressing board size, board independence, and board chair-CEO duality on various firm characteristics via the two-stage regression test. The sample used in these regressions includes observations from all samples and the sub-sample of each firm life cycle stage. We estimate board size and independence regressions by OLS, and board chair-CEO duality regressions by logistic regressions. The determinant variables are defined as above.

\begin{tabular}{|c|c|c|c|c|c|c|c|c|}
\hline \multirow[b]{2}{*}{ Variable } & \multicolumn{2}{|c|}{ All sample } & \multicolumn{2}{|c|}{ Sub-sample of Growth } & \multicolumn{2}{|c|}{ Sub-sample of Maturity } & \multicolumn{2}{|c|}{ Sub-sample of Decline } \\
\hline & Dsize & Indpd & Dsize & Indpd & Dsize & Indpd & dsize & Indpd \\
\hline & (1) & (2) & (1) & (2) & (1) & (2) & (1) & (2) \\
\hline \multirow[t]{3}{*}{ Size } & $0.422^{* * *}$ & $0.003^{* * *}$ & $0.126^{* * *}$ & 0.001 & $0.447^{* * *}$ & $0.003^{*}$ & $0.070^{*}$ & 0.001 \\
\hline & $(0.072)$ & $(0.0005)$ & $(0.045)$ & $(0.0008)$ & $(0.141)$ & $(0.0017)$ & $(0.038)$ & $(0.001)$ \\
\hline & $(\mathrm{p}=0.000)$ & $(\mathrm{p}=0.000)$ & $(\mathrm{p}=0.006)$ & $(\mathrm{p}=0.206)$ & $(\mathrm{p}=0.002)$ & $(p=0.073)$ & $(\mathrm{p}=0.092)$ & $(\mathrm{p}=0.237)$ \\
\hline \multirow[t]{3}{*}{ Segments } & -0.004 & -0.0004 & -0.183 & $-1.00 \mathrm{E}-03$ & $0.061^{*}$ & -0.0005 & -0.085 & -0.002 \\
\hline & $(0.286)$ & $(0.0004)$ & $(0.220)$ & $(0.001)$ & $(0.032)$ & $(0.001)$ & $(0.099)$ & $(0.0016)$ \\
\hline & $(\mathrm{p}=0.888)$ & $(\mathrm{p}=0.307)$ & $(\mathrm{p}=0.398)$ & $(p=0.378)$ & $(\mathrm{p}=0.059)$ & $(p=0.646)$ & $(\mathrm{p}=0.388)$ & $(\mathrm{p}=0.213)$ \\
\hline \multirow[t]{3}{*}{ Debt } & $0.305^{*}$ & $0.010^{* * *}$ & 0.661 & 0.008 & 0.368 & -0.021 & -0.249 & -0.004 \\
\hline & $(0.169)$ & $(0.003)$ & $(0.408)$ & $(0.013)$ & $(0.438)$ & $(0.014)$ & $(0.315)$ & $(0.004)$ \\
\hline & $(\mathrm{p}=0.072)$ & $(\mathrm{p}=0.000)$ & $(\mathrm{p}=0.105)$ & $(\mathrm{p}=0.530)$ & $(\mathrm{p}=0.400)$ & $(\mathrm{p}=0.140)$ & $(\mathrm{p}=0.430)$ & $(\mathrm{p}=0.331)$ \\
\hline \multirow[t]{3}{*}{ FirmAge } & $-0.014^{*}$ & -0.0001 & $-0.147^{* * *}$ & -0.001 & $-0.036^{*}$ & 0.0002 & -0.003 & $0.002^{* * *}$ \\
\hline & $(0.0074)$ & $(0.0002)$ & $(0.047)$ & $(0.001)$ & $(0.019)$ & $(0.0005)$ & $(0.043)$ & $(0.0007)$ \\
\hline & $(\mathrm{p}=0.058)$ & $(\mathrm{p}=0.584)$ & $(\mathrm{p}=0.002)$ & $(\mathrm{p}=0.301)$ & $(\mathrm{p}=0.060)$ & $(\mathrm{p}=0.686)$ & $(\mathrm{p}=0.940)$ & $(\mathrm{p}=0.004)$ \\
\hline
\end{tabular}


Appendix 1A. Continued

\begin{tabular}{|c|c|c|c|c|c|c|c|c|}
\hline \multirow[b]{2}{*}{ Variable } & \multicolumn{2}{|c|}{ All sample } & \multicolumn{2}{|c|}{ Sub-sample of Growth } & \multicolumn{2}{|c|}{ Sub-sample of Maturity } & \multicolumn{2}{|c|}{ Sub-sample of Decline } \\
\hline & Dsize & Indpd & Dsize & Indpd & Dsize & Indpd & dsize & Indpd \\
\hline \multirow[t]{3}{*}{ МТВ } & 0.018 & 0.001 & -0.076 & 0.002 & 0.012 & 0.002 & 0.053 & 0.001 \\
\hline & $(0.024)$ & $(0.0008)$ & $(0.059)$ & $(0.002)$ & $(0.060)$ & $(0.002)$ & $(0.048)$ & $(0.001)$ \\
\hline & $(\mathrm{p}=0.452)$ & $(\mathrm{p}=0.216)$ & $(\mathrm{p}=0.197)$ & $(\mathrm{p}=0.244)$ & $(\mathrm{p}=0.844)$ & $(\mathrm{p}=0.274)$ & $(\mathrm{p}=0.267)$ & $(p=0.286)$ \\
\hline \multirow[t]{3}{*}{ RETSTD } & $-0.729^{* *}$ & 0.009 & -0.862 & -0.053 & -0.522 & 0.004 & 0.880 & $0.057^{* *}$ \\
\hline & $(0.357)$ & $(0.010)$ & $(-1.413)$ & $(0.047)$ & $(0.470)$ & $(0.015)$ & $(2.933)$ & $(0.028)$ \\
\hline & $(\mathrm{p}=0.041)$ & $(\mathrm{p}=0.387)$ & $(\mathrm{p}=0.544)$ & $(\mathrm{p}=0.265)$ & $(\mathrm{p}=0.267)$ & $(p=0.767)$ & $(p=0.766)$ & $(\mathrm{p}=0.038)$ \\
\hline \multirow[t]{3}{*}{ FCF } & & -0.002 & & -0.020 & & 0.015 & & -0.008 \\
\hline & & $(0.005)$ & & $(0.018)$ & & $(0.018)$ & & $(0.010)$ \\
\hline & & $(\mathrm{p}=0.712)$ & & $(\mathrm{p}=0.257)$ & & $(\mathrm{p}=0.414)$ & & $(\mathrm{p}=0.443)$ \\
\hline \multirow[t]{3}{*}{ Perf } & & $-0.023^{* *}$ & & -0.013 & & -0.019 & & -0.020 \\
\hline & & $(0.011)$ & & $(0.041)$ & & $(0.031)$ & & $(0.020)$ \\
\hline & & $(\mathrm{p}=0.004)$ & & $(p=0.753)$ & & $(\mathrm{p}=0.535)$ & & $(\mathrm{p}=0.329)$ \\
\hline \multirow[t]{3}{*}{ CEOAge } & & -0.00002 & & -0.0003 & & $0.001^{*}$ & & -0.00004 \\
\hline & & $(0.001)$ & & $(0.003)$ & & $(0.00054)$ & & $(0.0003)$ \\
\hline & & $(\mathrm{p}=0.855)$ & & $(\mathrm{p}=0.278)$ & & $(\mathrm{p}=0.066)$ & & $(\mathrm{p}=0.898)$ \\
\hline \multirow[t]{3}{*}{ LagDual } & $-0.351^{* * *}$ & $0.008^{* * *}$ & $-0.246^{*}$ & $0.012^{* * *}$ & $-0.514^{* * *}$ & 0.008 & $-0.355^{* *}$ & 0.001 \\
\hline & $(0.060)$ & $(0.002)$ & $(0.132)$ & $(0.004)$ & $(0.168)$ & $(0.006)$ & $(0.164)$ & $(0.0036)$ \\
\hline & $(\mathrm{p}=0.000)$ & $(\mathrm{p}=0.000)$ & $(\mathrm{p}=0.062)$ & $(\mathrm{p}=0.008)$ & $(\mathrm{p}=0.002)$ & $(\mathrm{p}=0.156)$ & $(p=0.031)$ & $(\mathrm{p}=0.782)$ \\
\hline \multirow[t]{3}{*}{ Pre_Indpd } & 32.295 & & $-30.895^{* * *}$ & & -22.791 & & -53.350 & \\
\hline & $(43.642)$ & & (9.168) & & $(34.016)$ & & $(62.765)$ & \\
\hline & $(p=0.460)$ & & $(\mathrm{p}=0.001)$ & & $(p=0.501)$ & & $(\mathrm{p}=0.395)$ & \\
\hline \multirow[t]{3}{*}{ Pre_Dsize } & & $-0.008^{* * *}$ & & -0.006 & & $-0.017^{* * *}$ & & 0.012 \\
\hline & & $(0.002)$ & & $(0.006)$ & & $(-0.006)$ & & $(0.010)$ \\
\hline & & $(\mathrm{p}=0.001)$ & & $(\mathrm{p}=0.268)$ & & $(\mathrm{p}=0.003)$ & & $(\mathrm{p}=0.228)$ \\
\hline \multirow[t]{3}{*}{ MStkHd } & 0.020 & -0.001 & $1.968^{* * *}$ & 0.006 & 0.400 & -0.002 & 0.033 & $-0.020^{* *}$ \\
\hline & $(0.167)$ & $(0.006)$ & $(0.607)$ & $(0.007)$ & $(0.288)$ & $(0.010)$ & $(0.330)$ & $(0.008)$ \\
\hline & $(p=0.678)$ & $(\mathrm{p}=0.126)$ & $(\mathrm{p}=0.001)$ & $(\mathrm{p}=0.394)$ & $(p=0.165)$ & $(\mathrm{p}=0.840)$ & $(\mathrm{p}=0.920)$ & $(\mathrm{p}=0.017)$ \\
\hline \multirow[t]{3}{*}{ LgStkHd } & -0.010 & 0.0002 & $0.095^{* * *}$ & 0.00002 & 0.003 & 0.0001 & 0.023 & -0.0004 \\
\hline & $(0.010)$ & $(0.0002)$ & $(0.029)$ & $(0.0003)$ & $(0.010)$ & $(0.0004)$ & $(0.019)$ & $(0.0006)$ \\
\hline & $(p=0.293)$ & $(\mathrm{p}=0.290)$ & $(\mathrm{p}=0.001)$ & $(\mathrm{p}=0.937)$ & $(p=0.755)$ & $(\mathrm{p}=0.763)$ & $(p=0.217)$ & $(\mathrm{p}=0.523)$ \\
\hline \multirow[t]{3}{*}{ Constant } & -12.235 & $0.382^{* * *}$ & $12.359^{* * *}$ & $0.401^{* * *}$ & 7.261 & $0.418^{* * *}$ & 26.743 & $0.244^{* * *}$ \\
\hline & (17.732) & $(0.023)$ & (3.603) & $(0.055)$ & (15.127) & $(0.054)$ & (21.742) & $(0.090)$ \\
\hline & $(\mathrm{p}=0.488)$ & $(\mathrm{p}=0.000)$ & $(\mathrm{p}=0.001)$ & $(\mathrm{p}=0.000)$ & $(\mathrm{p}=0.631)$ & $(\mathrm{p}=0.003)$ & $(\mathrm{p}=0.218)$ & $(\mathrm{p}=0.007)$ \\
\hline Industry & Yes & Yes & Yes & Yes & Yes & Yes & Yes & Yes \\
\hline Year & Yes & Yes & Yes & Yes & Yes & Yes & Yes & Yes \\
\hline Observations & 5865 & 5865 & 1956 & 1956 & 2232 & 2232 & 1677 & 1677 \\
\hline Adj- $R^{2}$ & 0.083 & 0.059 & 0.13 & 0.064 & 0.106 & 0.062 & 0.086 & 0.099 \\
\hline $\mathrm{F}$ & $12.62^{* * *}$ & $8.62^{* * *}$ & $4.51^{* * *}$ & $2.53^{* * *}$ & $3.23^{* * *}$ & $2.17^{* * *}$ & $2.88^{* * *}$ & $3.06^{* * *}$ \\
\hline
\end{tabular}

Note: Standard errors are in parentheses, ${ }^{*} p<0.1,{ }^{* *} p<0.05,{ }^{* * *} p<0.01$ (two-tailed)

\section{Appendix Table 1B. Test Including Lag Variables}

This table reports results from regressing board size, board independence, and board chair-CEO duality on various firm characteristics, including the lay variables. The sample used in these regressions includes observations from all samples and the sub-sample of each firm life-cycle stage. We estimate board size and independence regressions by OLS, and board chair-CEO duality regressions by logistic regressions. The determinant variables are defined as above. 


\begin{tabular}{|c|c|c|c|c|c|c|c|c|}
\hline \multirow[b]{2}{*}{ Variable } & \multicolumn{2}{|c|}{ All sample } & \multicolumn{2}{|c|}{ Sub-sample of Growth } & \multicolumn{2}{|c|}{ Sub-sample of Maturity } & \multicolumn{2}{|c|}{ Sub-sample of Decline } \\
\hline & Dsize & indpd & Dsize & Indpd & dsize & Indpd & dsize & Indpd \\
\hline & (1) & (2) & (1) & (2) & (1) & (2) & (1) & (2) \\
\hline \multirow[t]{3}{*}{ Size } & $0.374^{* * *}$ & $0.004^{* * *}$ & $0.334^{* * *}$ & 0.002 & $0.478^{* * *}$ & 0.0003 & $0.145^{* *}$ & $0.006^{* *}$ \\
\hline & $(0.027)$ & $(0.001)$ & $(0.067)$ & $(0.002)$ & $(0.080)$ & $(0.003)$ & $(0.070)$ & $(0.0024)$ \\
\hline & $(\mathrm{p}=0.000)$ & $(\mathrm{p}=0.000)$ & $(\mathrm{p}=0.000)$ & $(\mathrm{p}=0.300)$ & $(\mathrm{p}=0.000)$ & $(\mathrm{p}=0.922)$ & $(\mathrm{p}=0.039)$ & $(\mathrm{p}=0.013)$ \\
\hline \multirow[t]{3}{*}{ Segments } & $-0.027^{* *}$ & $-0.0006^{*}$ & -0.059 & -0.001 & -0.060 & -0.001 & -0.027 & -0.001 \\
\hline & $(0.012)$ & $(.0 .0004)$ & $(0.055)$ & $(0.0007)$ & $(0.057)$ & $(0.001)$ & $(0.037)$ & $(0.001)$ \\
\hline & $(p=0.026)$ & $(\mathrm{p}=0.099)$ & $(\mathrm{p}=0.311)$ & $(\mathrm{p}=0.138)$ & $(\mathrm{p}=0.040)$ & $(\mathrm{p}=0.460)$ & $(\mathrm{p}=0.466)$ & $(\mathrm{p}=0.288)$ \\
\hline \multirow[t]{3}{*}{ Debt } & $0.121^{*}$ & 0.008 & 0.421 & 0.011 & 0.157 & 0.022 & -0.094 & -0.002 \\
\hline & $(0.071)$ & $(0.006)$ & $(0.383)$ & $(0.013)$ & $(0.408)$ & $(0.021)$ & $(0.107)$ & $(0.003)$ \\
\hline & $(\mathrm{p}=0.090)$ & $(\mathrm{p}=0.251)$ & $(\mathrm{p}=0.273)$ & $(\mathrm{p}=0.395)$ & $(\mathrm{p}=0.701)$ & $(\mathrm{p}=0.303)$ & $(\mathrm{p}=0.380)$ & $(\mathrm{p}=0.482)$ \\
\hline \multirow[t]{3}{*}{ FirmAge } & $-0.016^{* * *}$ & 0.0003 & -0.003 & -0.001 & -0.019 & 0.00003 & -0.017 & $0.001^{* *}$ \\
\hline & $(0.006)$ & $(0.0002)$ & $(0.021)$ & $(0.001)$ & $(0.017)$ & $(0.0006)$ & $(0.015)$ & $(0.0005)$ \\
\hline & $(p=0.004)$ & $(\mathrm{p}=0.132)$ & $(\mathrm{p}=0.890)$ & $(\mathrm{p}=0.308)$ & $(\mathrm{p}=0.272)$ & $(\mathrm{p}=0.964)$ & $(\mathrm{p}=0.269)$ & $(\mathrm{p}=0.028)$ \\
\hline \multirow[t]{3}{*}{ МТВ } & $0.039^{* * *}$ & $0.002^{* * *}$ & -0.048 & 0.002 & 0.002 & 0.002 & 0.042 & 0.001 \\
\hline & $(0.014)$ & $(0.0006)$ & $(0.056)$ & $(0.002)$ & $(0.040)$ & $(0.002)$ & $(0.032)$ & $(0.001)$ \\
\hline & $(\mathrm{p}=0.005)$ & $(\mathrm{p}=0.000)$ & $(\mathrm{p}=0.395)$ & $(\mathrm{p}=0.319)$ & $(p=0.964)$ & $(\mathrm{p}=0.320)$ & $(\mathrm{p}=0.187)$ & $(\mathrm{p}=0.370)$ \\
\hline \multirow[t]{3}{*}{ RETSTD } & $-0.595^{* *}$ & 0.010 & 0.064 & -0.049 & -0.497 & 0.002 & $-1.610^{* *}$ & $0.039^{*}$ \\
\hline & $(0.293)$ & $(0.010)$ & $(1.28)$ & $(0.044)$ & $(0.401)$ & $(0.018)$ & (0.688) & $(0.021)$ \\
\hline & $(\mathrm{p}=0.042)$ & $(\mathrm{p}=0.311)$ & $(\mathrm{p}=0.962)$ & $(\mathrm{p}=0.269)$ & $(\mathrm{p}=0.216)$ & $(p=0.911)$ & $(\mathrm{p}=0.019)$ & $(\mathrm{p}=0.067)$ \\
\hline \multirow[t]{3}{*}{ FCF } & & 0.002 & & -0.012 & & 0.007 & & -0.004 \\
\hline & & $(0.007)$ & & $(0.017)$ & & $(0.017)$ & & $(0.010)$ \\
\hline & & $(\mathrm{p}=0.781)$ & & $(\mathrm{p}=0.471)$ & & $(\mathrm{p}=0.674)$ & & $(\mathrm{p}=0.678)$ \\
\hline \multirow[t]{3}{*}{ Perf } & & $-0.030^{* * *}$ & & -0.036 & & -0.031 & & -0.018 \\
\hline & & $(0.011)$ & & $(0.040)$ & & $(0.028)$ & & $(0.018)$ \\
\hline & & $(\mathrm{p}=0.005)$ & & $(\mathrm{p}=0.369)$ & & $(\mathrm{p}=0.266)$ & & $(\mathrm{p}=0.330)$ \\
\hline \multirow[t]{3}{*}{ CEOAge } & & 0.0001 & & -0.0001 & & $0.001^{* *}$ & & -0.0001 \\
\hline & & $(0.0001)$ & & $(0.0003)$ & & $(0.0005)$ & & $(0.0003)$ \\
\hline & & $(\mathrm{p}=0.480)$ & & $(\mathrm{p}=0.714)$ & & $(\mathrm{p}=0.038)$ & & $(\mathrm{p}=0.711)$ \\
\hline \multirow[t]{3}{*}{ LagDual } & $-0.253^{* * *}$ & $0.004^{*}$ & -0.113 & $0.010^{* *}$ & $0.370^{* *}$ & 0.001 & $-0.311^{* *}$ & -0.002 \\
\hline & $(0.057)$ & $(0.0021)$ & $(0.126)$ & $(0.004)$ & (1.568) & $(0.004)$ & $(0.147)$ & $(0.005)$ \\
\hline & $(\mathrm{p}=0.000)$ & $(\mathrm{p}=0.055)$ & $(\mathrm{p}=0.367)$ & $(\mathrm{p}=0.022)$ & $(\mathrm{p}=0.019)$ & $(\mathrm{p}=0.796)$ & $(\mathrm{p}=0.035)$ & $(\mathrm{p}=0.709)$ \\
\hline \multirow[t]{3}{*}{ LagIndpd } & $-9.746^{* * *}$ & & $-8.734^{* * *}$ & & $-11.264^{* * *}$ & & $-12.701^{* * *}$ & \\
\hline & $(0.437)$ & & $(1.052)$ & & $(1.219)$ & & (1.062) & \\
\hline & $(\mathrm{p}=0.000)$ & & $(\mathrm{p}=0.000)$ & & $(\mathrm{p}=0.000)$ & & $(\mathrm{p}=0.000)$ & \\
\hline \multirow[t]{3}{*}{ LagDsize } & & $-0.010^{* * *}$ & & $-0.009^{* * *}$ & & $-0.011^{* * *}$ & & $-0.012^{* * *}$ \\
\hline & & $(0.0005)$ & & $(0.001)$ & & $(0.0012)$ & & $(0.001)$ \\
\hline & & $(\mathrm{p}=0.000)$ & & $(\mathrm{p}=0.000)$ & & $(\mathrm{p}=0.000)$ & & $(\mathrm{p}=0.011)$ \\
\hline \multirow[t]{3}{*}{ MStkHd } & 0.0890 & 0.001 & 0.069 & 0.007 & 0.240 & 0.001 & -0.109 & -0.019 \\
\hline & $(0.094)$ & $(0.026)$ & $(0.197)$ & $(0.006)$ & $(0.247)$ & $(0.004)$ & $(0.248)$ & $(0.008)$ \\
\hline & $(\mathrm{p}=0.342)$ & $(p=0.697)$ & $(\mathrm{p}=0.724)$ & $(\mathrm{p}=0.254)$ & $(\mathrm{p}=0.330)$ & $(\mathrm{p}=0.637)$ & $(p=0.661)$ & $(\mathrm{p}=0.014)$ \\
\hline LgStkHd & -0.001 & 0.0001 & 0.005 & 0.0001 & 0.007 & 0.0002 & 0.017 & -0.0001 \\
\hline & $(0.004)$ & $(0.0001)$ & $(0.007)$ & $(0.0004)$ & $(0.010)$ & $(0.0004)$ & $(0.017)$ & $(0.0005)$ \\
\hline & $(p=0.804)$ & $(p=0.370)$ & $(\mathrm{p}=0.480)$ & $(\mathrm{p}=0.823)$ & $(p=0.501)$ & $(\mathrm{p}=0.698)$ & $(\mathrm{p}=0.307)$ & $(\mathrm{p}=0.837)$ \\
\hline Constant & $4.297^{* * *}$ & $0.375^{* * *}$ & $5.719^{* * *}$ & $0.409^{* * *}$ & 2.139 & $0.414^{* * *}$ & $11.485^{* * *}$ & $0.414^{* * *}$ \\
\hline & $(0.624)$ & $(0.021)$ & $(1.554)$ & $(0.051)$ & (1.844) & $(0.060)$ & (1.009) & $(0.034)$ \\
\hline & $(\mathrm{p}=0.000)$ & $(\mathrm{p}=0.000)$ & $(\mathrm{p}=0.000)$ & $(\mathrm{p}=0.000)$ & $(\mathrm{p}=0.248)$ & $(\mathrm{p}=0.000)$ & $(p=0.000)$ & $(\mathrm{p}=0.000)$ \\
\hline Industry & Yes & Yes & Yes & Yes & Yes & Yes & Yes & Yes \\
\hline Year & Yes & Yes & Yes & Yes & Yes & Yes & Yes & Yes \\
\hline Observations & 5865 & 5865 & 1956 & 1956 & 2232 & 2232 & 1677 & 1677 \\
\hline Adj-R ${ }^{2}$ & 0.182 & 0.157 & 0.193 & 0.139 & 0.222 & 0.177 & 0.259 & 0.249 \\
\hline $\mathrm{F}$ & $29.650^{* * *}$ & $22.930^{* * *}$ & $6.640^{* * *}$ & $4.480^{* * *}$ & $6.360^{* * *}$ & $4.700^{* * *}$ & $7.990^{* * *}$ & $7.070^{* * *}$ \\
\hline
\end{tabular}

Note: Standard errors are in parentheses, ${ }^{*} p<0.1,{ }^{* *} p<0.05,{ }^{* * *} p<0.01$ (two-tailed)

(C) 2018 The International Association for Chinese Management Research 


\section{APPENDIX II. ROBUST TEST OF FIRM LIFE GYGLE}

\section{Appendix Table 2. Robust Test of Variable of Firm Life Gycle}

Using a sample of thirteen consecutive years of data, this table reports results from regressing board structure variables on firm life cycle, with year-fixed effects and industry-fixed effects controlled. Where the dependent variables comprise board structure that includes variables of board size, board independence and board chair-CEO duality, the independent variables comprise firm life-cycle variables including growth, maturity, decline, and the whole life cycle defined with coding sequential numbers. Columns (1), (3), and (5) estimate the effects of firm life cycle on board structure (including board size, independence, and board chair-CEO duality) with two life-cycle stage variables involved in the equation. Columns (2), (4), and (6) estimate the effects of firm life cycle on board structure (including board size, independence, and board chair-CEO duality), with life cycle variable involved in the equation.

\begin{tabular}{|c|c|c|c|c|c|c|}
\hline \multirow[b]{2}{*}{ Variables } & \multicolumn{2}{|c|}{ Dsize } & \multicolumn{2}{|c|}{ Indpd } & \multicolumn{2}{|c|}{ Dual } \\
\hline & 1 & 2 & 3 & 4 & 5 & 6 \\
\hline \multicolumn{7}{|l|}{ Growth } \\
\hline Maturity & $\begin{array}{c}0.030 \\
(0.098) \\
(\mathrm{p}=0.732)\end{array}$ & & $\begin{array}{c}-0.0001 \\
(0.0002) \\
(\mathrm{p}=0.643)\end{array}$ & & $\begin{array}{c}-0.038^{* * *} \\
(0.014) \\
(\mathrm{p}=0.006)\end{array}$ & \\
\hline Decline & $\begin{array}{c}-0.102^{*} \\
(0.053) \\
(\mathrm{p}=0.058)\end{array}$ & & $\begin{array}{c}-0.001 \\
(0.0013) \\
(\mathrm{p}=0.458)\end{array}$ & & $\begin{array}{c}-0.051^{* * *} \\
(0.014) \\
(\mathrm{p}=0.000)\end{array}$ & \\
\hline Life cycle & & $\begin{array}{c}-0.048^{*} \\
(0.025) \\
(\mathrm{p}=0.063)\end{array}$ & & $\begin{array}{c}-0.0001 \\
(0.00013) \\
(\mathrm{p}=0.449)\end{array}$ & & $\begin{array}{c}-0.026^{* * *} \\
(0.008) \\
(\mathrm{p}=0.001)\end{array}$ \\
\hline Constant & $\begin{array}{c}5.273^{* * *} \\
(0.310) \\
(\mathrm{p}=0.000)\end{array}$ & $\begin{array}{c}5.353^{* * *} \\
(0.314) \\
(\mathrm{p}=0.000)\end{array}$ & $\begin{array}{c}0.273^{* * *} \\
(0.010) \\
(\mathrm{p}=0.000)\end{array}$ & $\begin{array}{c}0.273^{* * *} \\
(0.011) \\
(\mathrm{p}=0.000)\end{array}$ & $\begin{array}{c}0.088^{*} \\
(0.051) \\
(\mathrm{p}=0.089)\end{array}$ & $\begin{array}{c}0.111^{* * *} \\
(0.052) \\
(\mathrm{p}=0.026)\end{array}$ \\
\hline Industry & Yes & Yes & Yes & yes & yes & yes \\
\hline Year & Yes & Yes & Yes & yes & yes & yes \\
\hline Observations & 5865 & 5865 & 5865 & 5865 & 5865 & 5865 \\
\hline Adj- $R^{2}$ & 0.051 & 0.052 & 0.164 & 0.164 & 0.042 & 0.042 \\
\hline $\mathrm{F}$ & $19.189^{* * *}$ & $20.569^{* * *}$ & $45.135^{* * *}$ & $46.948^{* * *}$ & $10.922^{* * *}$ & $11.319^{* * * *}$ \\
\hline
\end{tabular}

Note: Standard errors are in parentheses, ${ }^{*} p<0.1,{ }^{* *} p<0.05,{ }^{* * *} p<0.01$ (two-tailed)

\section{REFERENGES}

Adams, J. C., Mansi, S., \& Nishikawa, T. 2010. Internal governance mechanisms and operational performance: Evidence from index mutual funds. The Review of Financial Studies, 23(3): $1261-1286$.

Adams, R., \& Ferreira, D. 2007. A theory of friendly boards. Journal of Finance, 62(1): 217-250.

Adizes, I. 1989. How and why corporations grow and die and what to do about it: Corporate life cycle. Englewood Cliffs, NJ: Prentice Hall.

Anderson, C. R., \& Zeithaml, C. P. 1984. Stage of the product life cycle, business strategy, and business performance. Academy of Management Journal, 27(1): 5-24.

Anthony, J., \& Ramesh, K. 1992. Association between accounting performance measures and stock prices. Journal of Accounting and Economics, 15(2-3): 203-227.

Bens, D., Nagar, V., \& Wong, M. H. F. 2002. Real investment implications of employee stock option exercises.Journal of Accounting Research, 40(2): 359-393. 
Berle, A. A., \& Means, G. G. 1932. The modern corporation and private property. London: Macmillan.

Boone, A. L., \& Field, L. C. 2007. The determinants of corporate board size and composition: An empirical analysis. Journal of Financial Economics, 85(1): 66-101.

Booth, J., \& Deli, D. 1999. On executives of financial institutions as outside directors. Journal of Corporate Finance, 5(3): 227-250.

Borokhovich, K. A., Parrino, R., \& Trapani, T. 1996. Outside directors and CEO selection.Journal of Financial and Quantitative Analysis, 31(3): 337-55.

Brickley, J. A., Coles, J. L., \& Terry, R. L. 1994. Outside directors and the adoption of poison pills. Journal of Financial Economics, 35(3): 371-90.

Bushman, R., Chen, Q., Engel, E., \& Smith, A. 2004. Financial accounting information, organization complexity and corporate governance. Journal of Accounting and Economics, 37(2): 167201.

Carpenter, M. A., \& Westphal, J. D. 2001. The strategic context of external network ties: Examining the impact of director appointments on board involvement in strategic decision making. Academy of Management Journal, 44(4): 639-660.

Chandler, A. D. 1962. Strategy and structure: Chapters in the history of the American industrial enterprise: 283-319. Cambridge, MA: MIT Press.

Chen, W. 2007. Does the colour of the cat matter? The red hat strategy in China's private enterprises. Management and Organization Revieze, 3(1): 55-80.

Coles, J. L., Daniel, N. D., \& Naveen, L. 2008. Boards: Does one size fit all? Journal of Financial Economics, 87(2): 329-356.

Cummings, T. 2004. Organizational development and change. In J. Bonstra (Ed.), Dymamics of organizational change and learning: 133-148. West Sussex, UK: John Wiley \& Sons.

Dallas, L. L. 1996. The relational board: Three theories of corporate boards of directors. The Journal of Corporation Laze, 22(1): 1-25.

DeAngelo, H., DeAngelo, L., \& Stulz, R. 2006. Dividend policy and the earned/contributed capital mix: A test of the life-cycle theory. Journal of Financial Economics, 81(2): 227 254.

Dodge, H. J., Fullerton, S., \& Robbins, J. E. 1994. Stage of the organizational life cycle and competition as mediators of problem perception for small businesses. Strategic Management Journal, 15(2): 121-134.

Dodge, H. J., \& Robbins, J. E. 1992. An empirical investigation of the organizational life cycle model for small business development and survival. Journal of Small Business Management, 30(1): 27-37.

Drazin, R., \& Kazanjian, R. K. 1990. A reanalysis of Miller and Friesen's life cycle data. Strategic Management Journal, 11(4): 319-325.

Elsayed, K. 2010. A multi-theory perspective of board leadership structure: What does the Egyptian corporate governance context tell us? British Journal of Management, 21(1): 80-99.

Fama, E., \& Jensen, M. 1983. Separation of ownership and control. Journal of Laze and Economics, 26(2): 301-325.

Fan, J., Wong, T.J., \& Zhang, T. 2007. Politically connected CEOs, corporate governance, and post-IPO performance of China's newly partially privatized firms. Journal of Financial Economics, 84(2): 330-357.

Filatotchev, I., \& Wright, M. 2005. Corporate governance life-cycle. London: Edward Elgar.

Gaver, J., \& Gaver, K. 1993. Additional evidence on the association between the investment opportunity set and corporate financing, dividend, and compensation policies. Journal of Accounting and Economics, 16(1-3): 125-160.

Gillan, S. L., Hartzell, J. C., \& Starks, L. T. 2006. Tradeoffs in corporate governance: Evidence from board structures and charter provisions. Working Paper, University of Texas and Texas Tech University.

Golden, B. R., \& Zajac, E. J. 2001. When will boards influence strategy? Inclination x power = strategic change. Strategic Management Journal, 22(12): 1087-1111.

Goodstein, J., Gautam, K., \& Boeker, W. 1994. The effects of board size and diversity on strategic change. Strategic Management Journal, 15(3): 241-250.

Graham, J., \& Harvey, C. 2001. The theory and practice of corporate finance: Evidence from the field. Journal of Financial Economics, 60(2-3): 187-243.

Greiner, L. E. 1972. Evolution and revolution as organizations grow. Harvard Business Revieze, 50(4): $37-46$. 
Harris, M., \& Raviv, A. 1998. A theory of board control and size. Revieze of Financial Studies, 21(4): 1797-1832.

Hermalin, B., \& Weisbach, M. 1998. Endogenously chosen boards of directors and their monitoring of the CEO. American Economic Revieze, 88(1): 96-118.

Hillman, A., Cannella, A., \& Paetzold, R. 2000. The resource dependence role of corporate directors: Strategic adaptation of board composition in response to environmental change. Journal of Management Studies, 37(2): 235-256.

Hillman, A. J., \& Dalziel, T. 2003. Boards of directors and firm performance: Integrating agency and resource dependence perspectives. The Academy of Management Revieze, 28(3): 383-396.

Hribar, P., \& Yehuda, N. 2007. Life cycle, cost of capital, earnings persistence, and stock returns. Working paper, The University of Iowa and Columbia University.

Hu, H.W., Tam, O. K., \& Tan, M. G.-S. 2010. Internal governance mechanisms and firm performance in China. Asia Pacific Journal of Management, 27(4): 727-749.

Huang, M. 2010. Annual report of non-state-ozened economy in China No.7 (2009-2010). Beijing: Social Sciences Academic Press (China).

Hussain, S. H., \& Mallin, C. 2003.The dynamics of corporate governance in Bahrain: Structure, responsibilities and operation of corporate boards. Corporate Governance: An International Revieze, 11(3): 249-261.

Jawahar, I. M., \& McLaughlin, G. L. 2001. Toward a descriptive stakeholder theory: An organizational life cycle approach. Academy of Management Revieze, 26(3): 397-414.

Jensen, M. 1986. Agency costs of free cash flow, corporate finance, and takeovers. American Economic Revieze, 76(2): 323-329.

Jensen, M. 1993. The modern industrial revolution, exit and the failure of internal control systems, Journal of Finance, 48(3): 831-880.

Jensen, M., \& Meckling, W. 1976. Theory of the firm: Managerial behavior, agency costs, and capital structure. Journal of Financial Economics, 3(4): 305-360.

Johnson, J., Daily, C., \& Ellstrand, A. 1996. Boards of directors: A review and research agenda. Journal of Management, 22(3): 409-438.

Khurana, R. 2001. Finding the right CEO: Why boards often make poor choices. MIT Sloan Management Revieze, 43(1): 91-95.

Lasfer, M. 2006. The interrelationship between managerial ownership and board structure.Journal of Business Finance and Accounting, 33(7-8): 1006-1033.

Lehn, K., Patro, S., \& Zhao, M. 2009. Determinants of size and structure of corporate boards: 19352000. Financial Management, 38(4): 747-780.

Li, H., Meng, L., Wang, Q., \& Zhou, L. 2008. Political connection, financing and firm performance: Evidence from Chinese private firms. Journal of Development Economics, 87(2): 283-299.

Linck, J. S., Netter, J. M., \& Yang, T. 2007. A large sample study on board changes and determinants of board structure. Journal of Financial Economics, 85(1): 66-101.

Linck, J. S., Netter, J. M., \& Yang, T. 2008. The determinants of board structure. Journal of Financial Economics, 87(2): 308-328.

Lipton, M., \& Lorsch, J. W. 1992. A modest proposal for improved corporate governance. Business Lazeyer, 48(1): 59-77.

Luo, J. H., Wan, D. F., Cai, D., \& Liu, H. 2013. Multiple large shareholder structure and governance: The role of shareholder numbers, contest for control, and formal institutions in Chinese family firms. Management and Organization Revieze, 9(2): 265-294.

Lynall, M. D., Golden, B. R., \& Hillman, A. J. 2003. Board composition from adolescence to maturity: A multitheoretic. The Academy of Management Reviez, 28(3): 416-431.

Maug, E. 1997. Boards of directors and capital structure: Alternative forms of corporate restructuring. Journal of Corporate Finance, 3(2): 113-139.

Miller, D., \& Friesen, P. 1984. A longitudinal study of the corporate life cycle. Management Science, 30(10): 1161-1183.

Peng, M. W. 2004. Outside directors and firm performance during institutional transitions. Strategic Management Journal, 25(4): 453-471.

Peng, M. W., Li, Y., Xie, E., \& Su, Z. 2010. CEO duality, organizational slack and firm performance in China. Asia Pacific Journal of Management, 27(4): 61 1-624.

Peng, M. W., Sun, S. L., Pinkham, B., \& Chen, H. 2009. The institution-based view as a third leg for a strategy tripod. Academy of Management Perspectives, 23(3): 63-81.

Pfeffer, J. 1972. Size and composition of corporate boards of directors. Administrative Science Quarterly, 17(2): 218-229. 
Pfeffer, J., \& Salancik, G. 1978. The external control of organizations: A resource dependence perspective. New York: Harper \& Row.

Poncet, S., Steingress, W., \& Vandenbussche, H. 2010. Financial constraints in China: Firm-level evidence. China Economic Revieze, 21(3): 41 1-422.

Raheja, C. 2005. Determinants of board size and composition: A theory of corporate boards. Journal of Financial and Quantitative Analysis, 40(2): 283-306.

Roche, O. P. 2009. Corporate governance and organization life cycle: The changing role and composition of the board of directors. Amherst, New York: Cambria Press.

Owen, S., \& Yawson, A. 2010. Corporate life cycle and M\&A activity. Journal of Banking \& Finance, 34(2): 427-440.

Smith, C., \& Watts, R. 1992. The investment opportunity set and corporate financing, dividend, and compensation policies. Journal of Financial Economics, 32(3): 263-292.

Wintoki, M. B., Linck, J. S., \& Netter, J. M. 2012. Endogeneity and the dynamics of internal corporate governance. Journal of Financial Economics, 105(3): 581-606.

Young, M. N., Peng, M. W., Ahlstrom, D., Bruton, G. D., \& Jiang, Y. 2008. Corporate governance in emerging economies: A review of the principal-principal perspective. Journal of Management Studies, 45(1): 196-220.

Yunhe Li (yhli@sfs.ecnu.edu.cn) is an associate professor of Finance in School of Economics at East China Normal University. He received his $\mathrm{PhD}$ in Finance from Shanghai Jiao Tong University. He was a visiting scholar in Finance department at NYU Stern School of Business. His research focuses on Corporate Governance, Corporate Finance and Corporate Innovation. His work has appeared in Asia Pacific Journal of Innovation and Entrepreneurship, Management and Organization Review, and Chinese Journals. He received Research Grants of National Social Science Fund of China (13CGL048) and Social Science Fund of Shanghai (2012EJB003). The paper is supported by both the two funds.

Xiaotian Tina Zhang (xz4@stmarys-ca.edu) received her PhD in Finance from Temple University. She is an Associate Professor of Finance and Chevron Professor at Saint Mary's College of California. She has been the Chair of Department of Finance and is the Founding Director of China EMBA program at Saint Mary's College. She has published her studies in a number of academic journals, including Global Economic Review, Global Strategy Journal, International Finance Review, Managerial Finance, Management and Organization Review, and Small Business Economics. She is a recipient of the Provost's Faculty Research Grant and SEBA's Outstanding Research Award at Saint Mary's College. Her current research investigates corporate restructure decisions and effects of financial sentiment indices on stock performance.

Manuscript received: May 8, 2015

Final version accepted: September 21, 2017 (number of revisions - 5)

Accepted by: $\quad$ Senior Editor Xiaowei Rose Luo 